\title{
The indigenous settlement of Monte lato (western Sicily): an ethnoarchaeometric approach for outlining local Archaic ceramic productions
}

\author{
G. Montana ${ }^{1}$ (D) A. M. Polito ${ }^{1}$ - E. Kistler ${ }^{2} \cdot$ M. Mohr $^{3} \cdot$ F. Spatafora ${ }^{4}$ \\ Received: 27 March 2021 / Accepted: 14 June 2021 / Published online: 3 August 2021 \\ (C) The Author(s) 2021
}

\begin{abstract}
An ethnoarchaeometric approach has been followed to identify the textural and compositional characteristics of the ceramic pastes produced in ancient Iaitas/Ietas, an indigenous site located in western Sicily on Monte Iato, a few tens of kilometres from Palermo. This approach was primarily motivated by the lack of discovered Archaic kilns or production sites/workshops and the inability to identify reference groups. Raw clays were sampled in the territory of San Cipirello and San Giuseppe Iato (today's municipalities both sited on the northern slopes of Monte Iato), together with representative historic tiles and bricks locally produced until fairly recently. Grain-size analysis and experimental firings were performed on the clay samples. A significant number of archaeological ceramic samples (incised and painted indigenous pottery dating back to the seventh-fifth centuries BCE) from stratigraphic excavations on Monte Iato, and hypothesized as local productions on a stylistic-morphological basis, was carefully selected for archaeometric analysis. This set of samples (90 in total, comprising raw clays, historic tiles/bricks and archaeological ceramics) underwent a combined chemical and mineralogical-petrographic analysis to identify any possible compositional matching. This approach enabled the identification of minero-petrographic and chemical markers pertinent to the indigenous Archaic pottery produced at Monte Iato, although no evidence of coeval ceramic kilns has been found so far. Local raw clay sources have been documented and some significant points of the chaîne opératoire adopted in antiquity have been noted (clay mixing and tempering practices). Attesting Monte Iato as a centre of ceramic production and defining both the microscopic fabric and the average composition of local pastes open up new perspectives in the complex issue concerning the production and regional circulation of incised and painted indigenous ceramics in Archaic Sicily.
\end{abstract}

Keywords Sicily · Archaic age (seventh-fifth century BCE) - Monte Iato - Ceramic production · Clay sources · Ethnoarchaeometry

G. Montana

giuseppe.montana@unipa.it

1 Dipartimento di Scienze della Terra e del Mare (DiSTeM), Università di Palermo, Palermo, Italy

2 Institut für Archäologien - Fachbereich Klassische und Provinzialrömische Archäologie, Universität Innsbruck, Innsbruck, Austria

3 Institut für Archäologie - Fachbereich Klassische Archäologie, Universität Zürich, Zürich, Switzerland

4 Regione Siciliana, Parco Archeologico di Himera, Solunto e Iato, Palermo, Italy

\section{Archaeological background and aims}

Located among the mountains in the midlands of western Sicily, Monte Iato (DPS coordinates: $37^{\circ} 58^{\prime} 024^{\prime \prime} \mathrm{N} 13^{\circ} 11^{\prime}$ $52.6^{\prime \prime} \mathrm{E} ; 852 \mathrm{~m}$ above sea level) was positioned at the border of the Greek and Phoenician coastal world both topographically and culturally (Fig. 1). Monte Iato was settled by the early seventh century BCE, at the latest, because of the advantages of this central position. A dispersed settlement composed of small oval and/or rectangular dwellings and arranged in several compounds is attested for the first half of the sixth century BCE, the inhabitants of which had hospitable partnerships with Phoenicians and Greeks. This hilltop settlement experienced its first flourishing of inter-regional relevance and range as early as the late sixth and early fifth century 


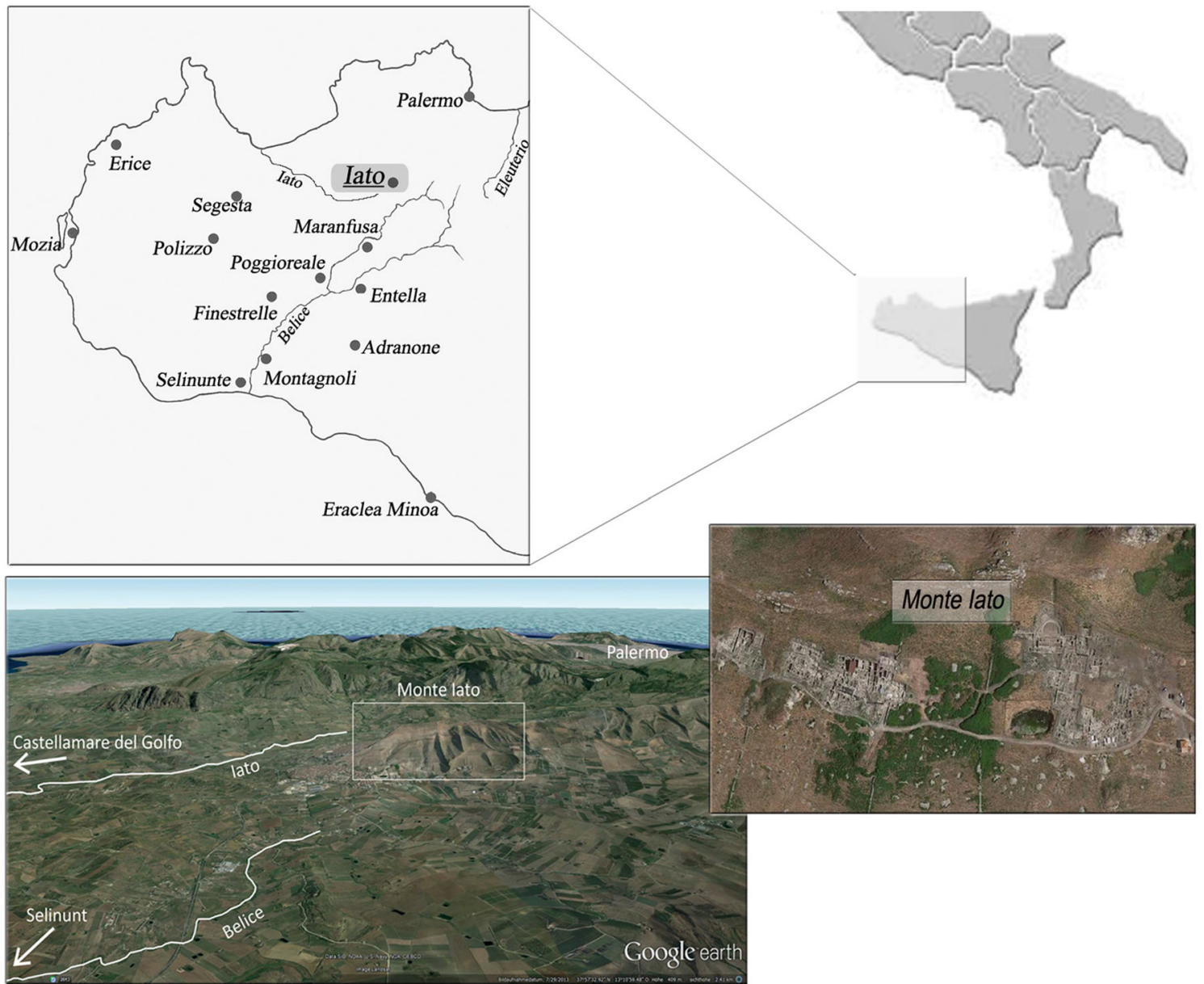

Fig. 1 Location of the studied area in the Archaic western Sicily. The site of Monte Iato (aerial view)

BCE. This heyday is particularly evidenced by the cult site around the Aphrodite temple in the western quarter of the later Hellenistic-Roman city (Fig. 2). This temple was built in the last quarter of the sixth century BCE by Greek builders. In the following period, further Archaic sacred buildings in the
Greek oikos-type were erected to the east of the temple. Along with the temple of Aphrodite, which had an altar made of limestone blocks in its forecourt, these oikoi, used as club and festival houses by Greek partners, mark an intra-regional cult centre. This also included the Late Archaic house built

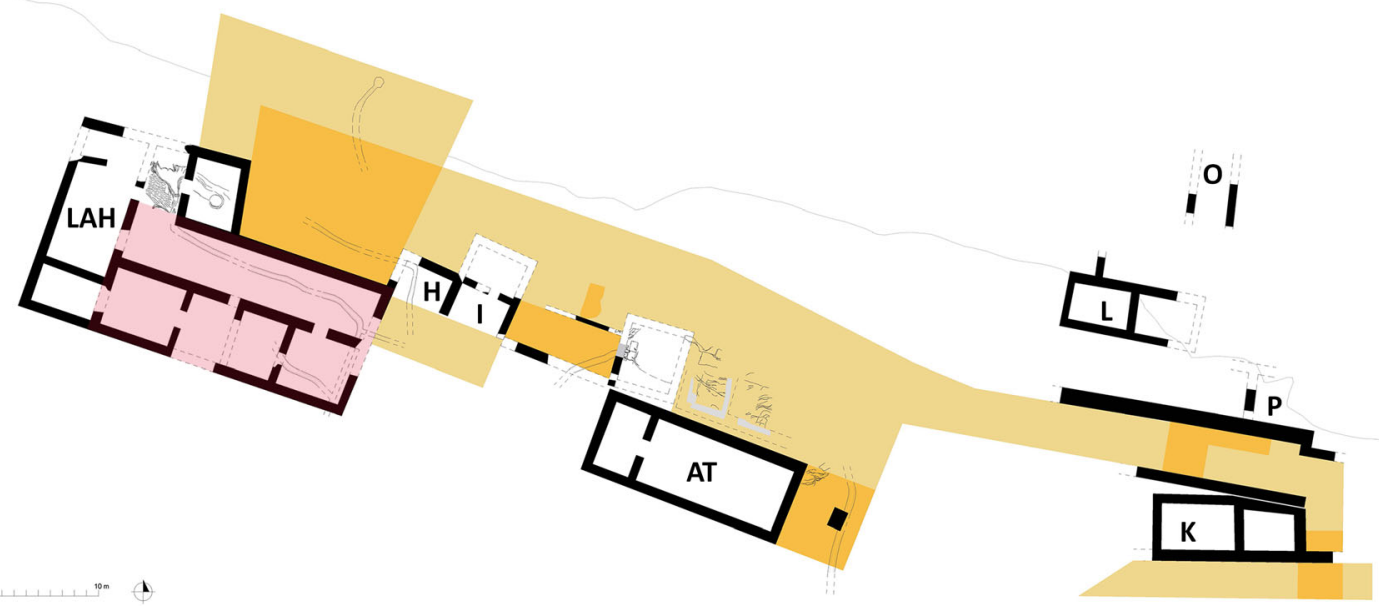

Fig. 2 Cult site around the Aphrodite temple (AT) in the western quarter with the Late Archaic house (LAH) to the west and several sacral connoted buildings ( $\mathrm{K}, \mathrm{L}, \mathrm{P}$ and $\mathrm{O}$ ) to the east 
shortly before 500/480 BCE, equipped on its upper floor with representatively furnished triclinia or dining couches. Around 460/50 BCE, however, the Late Archaic house was ritually destroyed at the same time as the temple of Aphrodite was abandoned. This was followed by a period of roughly a hundred years in which there were neither imports nor a stable settlement. During these dark ages, contacts and interconnections with Greeks and Phoenicians were interrupted. It was not until the beginning of the third century BCE that the colonial power matrix on Monte Iato was reborn and in which in Hellenistic-Roman Iaitas/Ietas flourishes with a theatre, an agora, a bouleuterion and peristyle houses (Isler 2000; Kistler and Mohr 2015, 2016; Mohr 2019, 2021).

Since 2011, archaeological research on Monte Iato has focused on how complex processes of group and identity negotiation, triggered by interconnections with Greek settlers, were mediated and manifested in daily practice through material culture, including pottery. These processes ultimately determined the local demands concerning traditional, hybrid or Greek-styled pottery as identity-expressing media. Moreover, it was these different demands for pottery to which the local potters ultimately reacted. However, to investigate such local potters' reactions, it is essential to determine local types of clay and the resulting paste fabrics that local workshops used to make ceramics. This requires findings from pottery kilns as well as from misfired wasters, which allow the identification of local reference groups. Unfortunately, neither kilns nor wasters have come to light on Monte Iato (Kistler 2017; Kistler et al. 2017). This research, funded by the Jubiläumsfond der Österreichischen Nationalbank (project nr. 14960), therefore had to be conducted using an alternative ethnoarchaeometric approach which, in its initial stage, was primarily focused on geological field survey and the compositional characterization of local ceramic raw materials.

In the last 15 years, indigenous ceramics have been the subject of archaeometric studies aimed at identifying the production centres located in western Sicily (Kolb and Speakman 2005; Montana et al. 2011a; Montana et al. 2012). The chemical and mineralogical compositions of the clayey materials suitable for pottery production have already been published (Montana et al. 2011b; Montana et al. 2011c). Different work strategies were undertaken on this experienced methodological basis, with the aim of identifying the textural and compositional characteristics of the ceramic pastes produced in ancient Iaitas/Ietas. First, old potters who worked the last active ceramic kilns in the villages were interviewed to pinpoint the supply areas for raw clays and to reconstruct the local traditional chaîne opératoire. Then, raw clays were sampled in the territory of San Cipirello and San Giuseppe Iato (current municipalities situated on the northern slopes of Monte Iato; DMS coordinates: San Cipirello, 37 $57^{\prime} 42.0^{\prime \prime} \mathrm{N} 13^{\circ} 10^{\prime} 37.9^{\prime \prime}$ E; San Giuseppe Iato, $37^{\circ} 58^{\prime} 14.3^{\prime \prime} \mathrm{N} 13^{\circ} 10^{\prime} 57.8^{\prime \prime} \mathrm{E}$ ) together with representative historic tiles and bricks locally produced in the last few centuries. Grain-size analysis and experimental firings were performed on the clay samples. In addition, a significant number of archaeological ceramic samples (seventh-fifth century BCE) deriving from stratigraphic excavations on Monte Iato and presumed to be of local production on a stylistic-morphological basis were optically selected for archaeometric analysis. Finally, this assorted set of samples (90 in total comprising raw clays, historic tiles/bricks and archaeological ceramics) was subjected to mineralogical, petrographic and chemical analysis to establish via crosscomparison any relevant compositional markers of local Archaic indigenous productions.

\section{General geological setting and raw clay materials}

The area under study lies about $30 \mathrm{~km}$ south-west of Palermo. It has recently been the topic of an official geological survey within the CARG Project, coordinated by the Geological Service of Italy, and falls within the Foglio 607 Corleone (Catalano et al. 2010; Gasparo Morticelli et al. 2017). The geomorphological structure of this area is expressed by two different landscapes: The first is hilly and predominantly clayey and affected by fluvial processes; the second is mainly mountainous, located in the north-eastern sector, characterized by the W-E mountain ridge of Monte Iato-Monte Giuhai (whose highest peak, Monte Kumeta, reaches 1233 m above sea level) and the southern edge of Monte Pizzuta. The most important lithological successions exposed in the abovementioned reliefs are represented by carbonate platform and basin deposits of the Triassic-Liassic age, followed by deposits of carbonate platform and basin of the JurassicOligocene age. They are followed by clastic deposits of the Oligocene-lower Miocene and discordant on evaporitic and clastic deposits of the upper Miocene-Pleistocene interval (Fig. 3).

From the bottom to the top, the following lithostratigraphic units are well exposed in Monte Iato and its northern and western slopes: (1) Inici Formation (white algal limestones and dolomitic limestones alternated with stromatolitic and lopheritic limestones), Hettangian-Sinemurian; (2) Hybla Formation (marly calcilutite with chert and greenish marls with calcareous plankton, benthonic foraminifera and radiolarians), Upper Valanginian-Albian; (3) Amerillo Formation (limestones with chert layers and planktonic foraminifera), upper Cretaceous-Eocene; (4) Corleone Calcarenites (biocalcirudites and glauconite-bearing arenites), Burdigalian-Langhian; (5) Tavernola Formation (marls and greenish pelites with planktonic foraminifera and abundant glauconite), Upper Aquitanian-Langhian; (6) Marne di San Cipirello Formation (clays and marly clays with abundant planktonic foraminifera), Serravallian-Lower Tortonian; and 


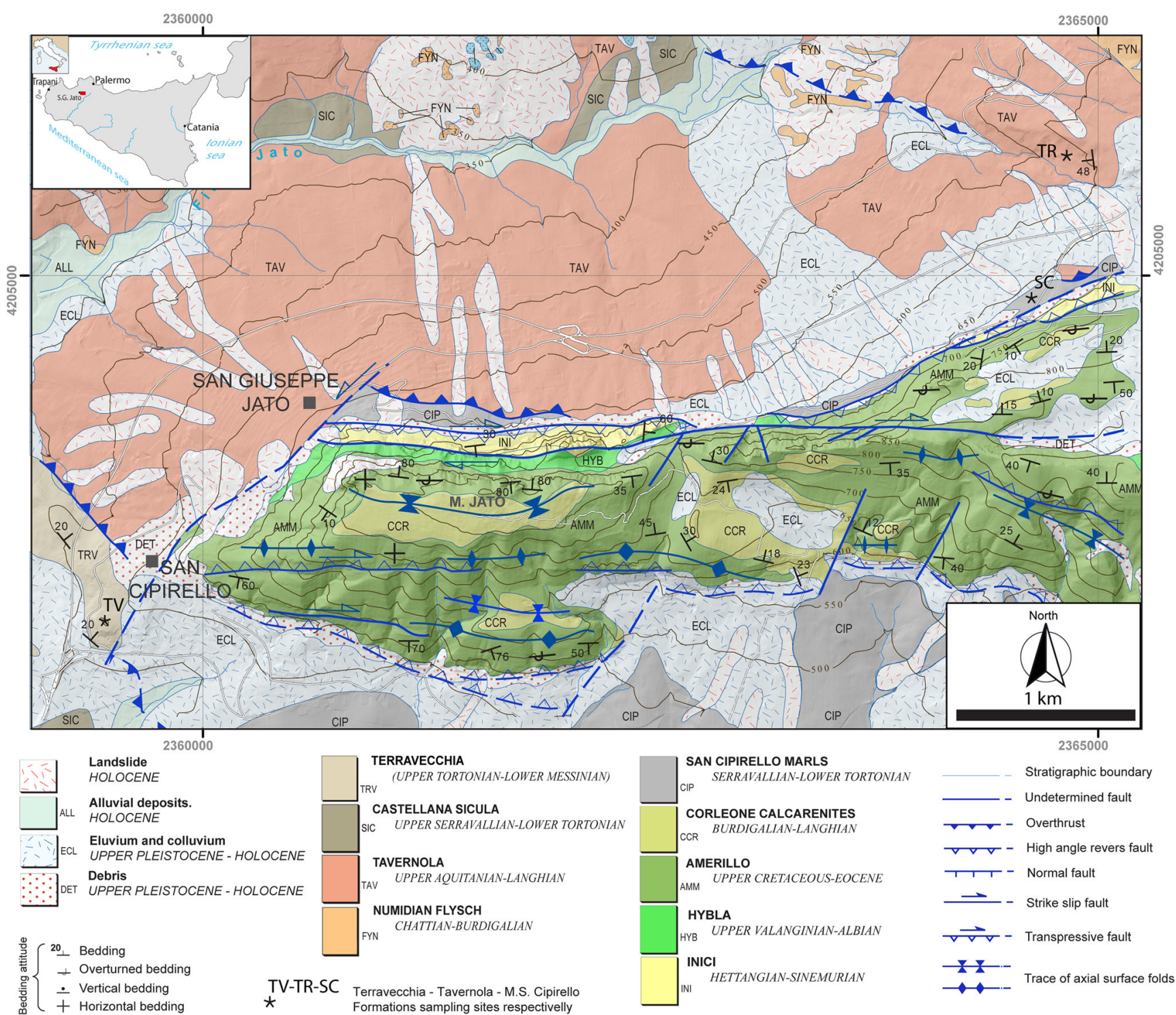

Fig. 3 Geological map of the area (simplified sketch after Gasparo Morticelli et al. 2017)

(7) Terravecchia Formation (includes terrigenous deposits with different granulometries that allow the separation of the formation into homogeneous units constituted of (from bottom to top) conglomerates with sand-silty matrix with carbonate, arenaceous and acid crystalline elements; sands and quartz sandstones of grey-yellowish colour rich in mica; silty clays with scarce calcareous plankton and benthic foraminifera), Upper Tortonian-Lower Messinian.

From the above-described picture, the lithostratigraphic units consisting of clayey-silty deposits theoretically suitable for ceramics and outcropping on the northern slopes of Monte Iato belong to the Tavernola Formation, Marne di San Cipirello Formation and Terravecchia Formation. The Tavernola Formation, ascribed to the lower-middle Miocene, is characterized by greenish-grey marls and pelites, generally interbedded with thin arenaceous levels rich in quartz and glauconite granules. The paleontological content of the clayey marls is given by radiolarian, sponge spicules, planktonic foraminifera, benthic foraminifera and more rarely calcareous nannofossils. The stratigraphic unit of the Marne di San Cipirello, of the middle-upper Miocene, includes marls and clayey marl of grey-greenish colour with scarce quartz sand and a rich microfauna composed of prevalent calcareous plankton. The pelitic member of the Terravecchia Formation is assigned to the upper Miocene and is represented as clayey silts and sandy argillites with benthic fauna and poor calcareous plankton.

\section{Sampling}

After interviewing the potters, clay was sampled in the neighbourhoods of San Cipirello and San Giuseppe Iato. 
The zones in which local craftsmen exploited suitable clays for the traditional manufacture of structural fired clay products (tiles and bricks) have thus been localized. The methods of extracting (pit quarries) and ageing raw clayey materials and the procedures for modelling (handmade shaping), drying and firing the finished products have been attested. However, field surveys soon revealed a shortage of representative clay outcroppings in the area. The urban expansion of the aforementioned small towns, associated with the intensive use of the exposed soil for agriculture, have made relatively more problematic the recovery of fresh deposits that are truly representative (from a mineralogical and chemical point of view) of the geological formations already identified as potential sources of ceramic-use clays. For this reason, after a first collection of up to 20 clay samples for laboratory analysis, only 10 were selected and considered reasonably representative of local geo-materials. In general, on-field clay collection $(1-2 \mathrm{~kg})$ was made along natural soil incisions or recent anthropogenic excavations (1-3 m depth). This procedure allowed us to avoid significant contamination deriving from cultivated soil (textural and compositional) as much as possible. The selected samples are listed in Table 1, where individual sampling points and geological nature (on a cartographic basis) are specified. The samples near the inhabited area of San Cipirello (CIP 12, CIP 13, CIP 14, CIP 15) are representative of the most pelitic levels of the Terravecchia Formation.

The samples attributed to the Marne di S. Cipirello Formation (samples CIP 7, CIP 8 and CIP 9) were taken to the east of San Giuseppe Iato, not far from the ancient medieval mule track known as scala di ferro, which climbs up the northern side of Monte Iato leading near the eastern gate of the ancient settlement. The sampling of the Tavernola Formation (CIP 2, CIP 5, CIP 6) was carried out in the westernmost part of the examined area, corresponding to stream incisions degrading in the Iato River valley (Fig. 4A).

Twenty traditional fired ceramic building materials and clay products (Table 2) were sampled, based on the testimonies of the descendants of ceramists, who enabled access to three disused ceramic kilns located within private properties for sampling bricks and tiles certainly produced during the last century with the clayey raw materials available in the surrounding area. Representative ceramic fragments (100-200 g) were taken from the ruins of old walls and collapsed roofs to have a reference term for textural, mineralogical and chemical characteristics of ceramic products manufactured from locally available clays (Fig. 4B).

Finally, up to 60 archaeological ceramic samples for laboratory research were selected from a much larger number of finds from the excavations carried out at Monte Iato by the Universities of Zurich and Innsbruck. These exclusively consisted of matt-painted and/or incised Archaic indigenous ceramics, which date from the seventh century to the first half of the fifth century BCE (Table 3). Different types of traditional pottery are represented, for the most part characterized by geometric patterns (painted and incised), including hydrias, bowls, jugs, basins, cups and craters (Fig. 5). We took into account both the abundance and the macroscopic characteristics for typological selection.

\section{Methods}

Of the 80 ceramic samples $(20$ deriving from the ethnoarchaeometric survey and 60 from the archaeological excavations), after drying in the oven at $50{ }^{\circ} \mathrm{C}$ for $48 \mathrm{~h}$, two fragments (about $4 \mathrm{~g}$ each) were taken for petrographic (thinsection microscopy) and chemical analysis (combined ICPOES and ICP-MS).

The preparation of the 10 raw clay samples ( $1-2 \mathrm{~kg}$ each) was more complex. They were first placed to dry in the laboratory at room temperature for 1-2 weeks and then gently crushed in a porcelain mortar. At the end of these pre-treatments, after careful quartering, four different amounts were taken from each sample, to be respectively assigned to the grain-size analysis routine, to elemental chemical analysis and to experimental firing. Experimental clay briquettes (12 x $5 \times 1.5 \mathrm{~cm}$ ) were made and fired at $900{ }^{\circ} \mathrm{C}$ (oxidant atmosphere) to obtain thin sections to be observed under the polarizing microscope. About $50 \mathrm{~g}$ of the quartered clay material was dried in an oven at $60{ }^{\circ} \mathrm{C}$ for $48 \mathrm{~h}$ and afterwards left in
Table 1 Sampling point and geological references of the studied clayey deposits

\begin{tabular}{|c|c|c|c|}
\hline Code & $\begin{array}{l}\text { Sampling } \\
\text { point }\end{array}$ & Clay formation & $\begin{array}{l}\text { DMS geographical } \\
\text { coordinates }\end{array}$ \\
\hline \multirow[t]{2}{*}{ Cip 2-Cip 5-Cip 6} & Casa & Tavernola Formation (Upper & $37^{\circ} 58^{\prime} 56.45^{\prime \prime} \mathrm{N}$ \\
\hline & $\begin{array}{l}\text { Acquaro- } \\
\text { ne }\end{array}$ & Aquitanian-Langhian) & $13^{\circ} 14^{\prime} 0.95^{\prime \prime} \mathrm{E}$ \\
\hline \multirow[t]{2}{*}{ Cip 7-Cip 8-Cip 9} & Contrada & S. Cipirello Formation (Serravallian-Lower & $37^{\circ} 58^{\prime} 43.57^{\prime \prime} \mathrm{N}$ \\
\hline & Ginestra & Tortonian ) & $13^{\circ} 13^{\prime} 34.34^{\prime \prime} \mathrm{E}$ \\
\hline \multirow{2}{*}{$\begin{array}{c}\text { Cip 12-Cip 13-Cip } \\
\text { 14-Cip } 15\end{array}$} & Via E. & Terravecchia Formation (Upper & $37^{\circ} 57^{\prime} 35.07^{\prime \prime} \mathrm{N}$ \\
\hline & $\begin{array}{l}\text { Berlingu- } \\
\text { er }\end{array}$ & Tortonian-Lower Messinian) & $13^{\circ} 10^{\prime} 25.10^{\prime \prime} \mathrm{E}$ \\
\hline
\end{tabular}



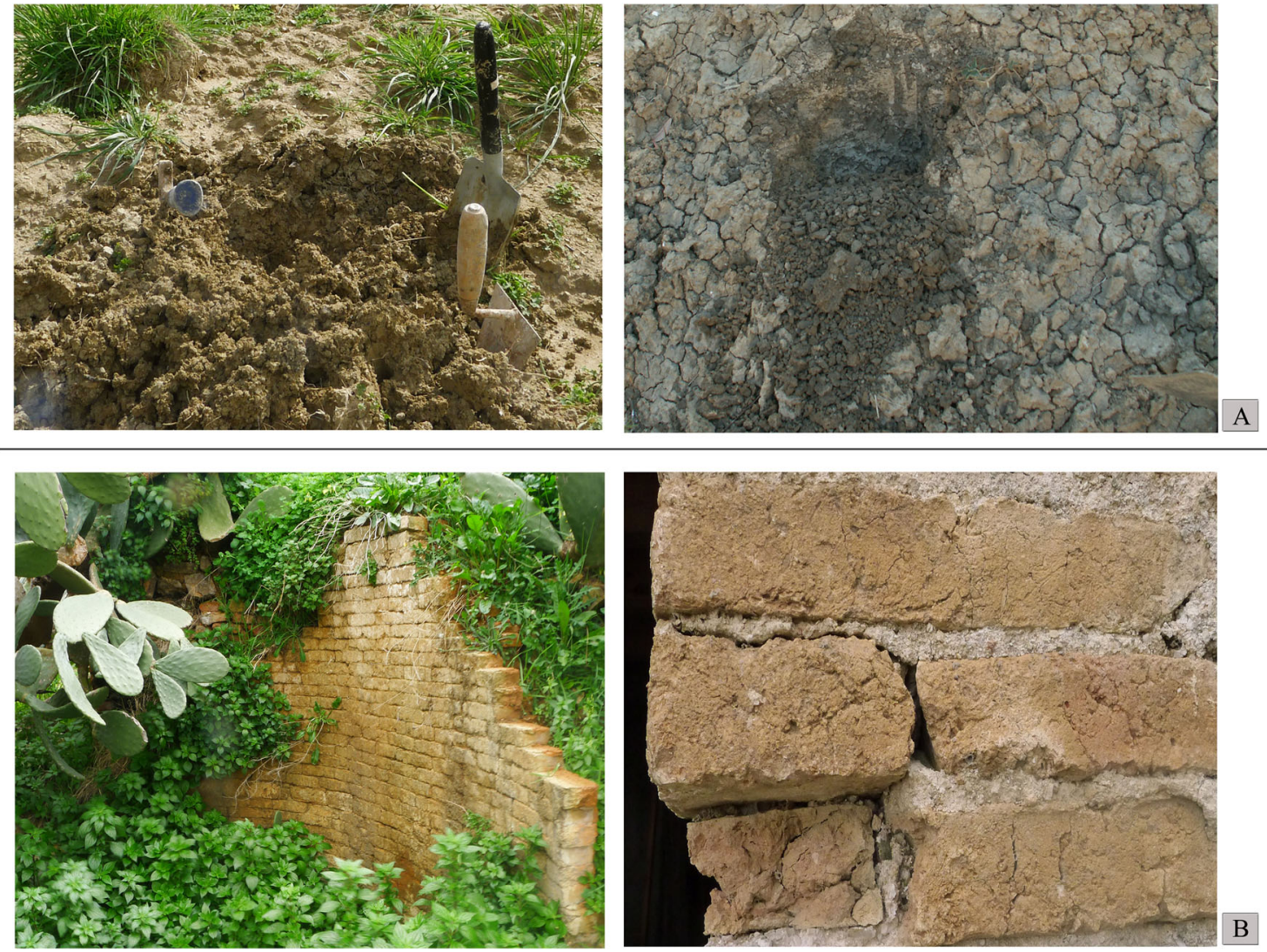

Fig. 4 A Examples of raw clay sampling (left, sample CIP7; right, sample CIP14). B Examples of local traditional brick/tile sampling (left, ruins of an old ceramic kiln at San Cipirello; right, SCP2 sampling point)

storage with silica gel to cool to room temperature. This amount was carefully weighed using an analytical balance (measuring limit $0.1 \mathrm{mg}$ ), mixed with de-ionized water and further dispersed in an ultrasonic bath. The sand fraction was first separated according to Stokes' law and then dried in an oven $\left(60{ }^{\circ} \mathrm{C}\right)$ for $48 \mathrm{~h}$ and weighed. The remaining water suspension containing the silt and clay fractions was further disaggregated by means of an ultrasonic bath. The silt fraction was separated through a centrifuge cycle at $2500 \mathrm{rpm}$ and was then consistently dried out and weighed by analytical balance.

Optical microscopy was carried out on all ceramic samples with a Leica DC 200 polarizing microscope equipped with a digital camera, which allowed classification of the analysed material according to the mineralogical composition and textural characteristics of the aplastic components and groundmass. Comparative tables were used in the evaluation of relative abundance of aplastic grain (area\%, after Mathew et al. 1991).

For more objective and accurate interpretation of the petrographic results (that would otherwise be qualitative), multiple correspondence analysis (MCA) was performed on data composed of the categorical petrographic variables (binary variables $0-1$ ) such as grain-size distribution, packing, sorting, absence and/or presence (and relative abundance) of minerals and lithic fragments and presence or absence of aplastic inclusions following the procedure described in Cau
Table 2 Sampling point and typology of the studied traditional brick/tiles

\begin{tabular}{|c|c|c|c|}
\hline Code & Typology & Sampling point & $\begin{array}{l}\text { DMS geographical } \\
\text { coordinates }\end{array}$ \\
\hline Scp1-Scp2 & Brick & \multirow{2}{*}{$\begin{array}{l}\text { S. Cipirello (Termine's Kiln, } \\
\text { via Trento) }\end{array}$} & $37^{\circ} 57^{\prime} 35.9^{\prime \prime} \mathrm{N}$ \\
\hline Scp3-Scp4 & Tile & & $13^{\circ} 10^{\prime} 59.9^{\prime \prime} \mathrm{E}$ \\
\hline \multirow[t]{2}{*}{ Scp5-Scp6-Scp7-Scp8-Scp9-Scp10-Scp11 } & \multirow[t]{2}{*}{ Brick } & \multirow{2}{*}{$\begin{array}{l}\text { S. Giuseppe Iato (Mannino's } \\
\text { Kiln, via Falde) }\end{array}$} & $37^{\circ} 58^{\prime} 14.6^{\prime \prime} \mathrm{N}$ \\
\hline & & & $13^{\circ} 11^{\prime} 54.1^{\prime \prime} \mathrm{E}$ \\
\hline Scp12-Scp15-Scp16-Scp17 & Tile & \multirow{2}{*}{$\begin{array}{l}\text { S. Cipirello (Termine's } \\
\text { Kiln, via Salvato) }\end{array}$} & $37^{\circ} 57^{\prime} 38.7^{\prime \prime} \mathrm{N}$ \\
\hline Scp13-Scp14-Scp18-Scp19-Scp20 & Brick & & $13^{\circ} 10^{\prime} 31.5^{\prime \prime} \mathrm{E}$ \\
\hline
\end{tabular}


Table 3 Schematic description of the analysed archaeological ceramic samples

\begin{tabular}{|c|c|c|c|c|}
\hline Samples $=60$ & Typology & Decoration & Chronology & DMS geographical coordinates \\
\hline IK 42 & hydria/amphora & Incised-geometric & Archaic & $37^{\circ} 58^{\prime} 02.4^{\prime \prime} \mathrm{N}$ \\
\hline IK 313 & Open form & Incised-geometric & Archaic & $13^{\circ} 11^{\prime} 52.6^{\prime \prime} \mathrm{E}$ \\
\hline IK 418 & Bowl & Incised-geometric & Archaic & \\
\hline IK 460 & Bowl & Incised-geometric & Archaic & \\
\hline IK 792 & Bowl & Incised-geometric & Archaic & \\
\hline IK 923 & Bowl & Incised-geometric & Archaic & \\
\hline IK 937 & Bowl & Incised-geometric & Archaic & \\
\hline IK 1262 & Bowl & Incised & Archaic & \\
\hline K 10769 B & Crater & Painted-geometric & Late archaic & \\
\hline K 16588 & Hydria/amphora & Painted-geometric & Late archaic & \\
\hline K $17218 \mathrm{C}$ & Jug & Painted-geometric & Late archaic & \\
\hline K 17220 B & Stamnos & Painted-geometric & Late archaic & \\
\hline K 17249 & Bowl & Painted-geometric & Late archaic & \\
\hline K 17293 & Jug & Painted-geometric & Late archaic & \\
\hline K 19201 & Crater & Painted-geometric & Late archaic & \\
\hline K 19340 & Bowl & Painted-geometric & Late archaic & \\
\hline K 19366 & Jug & Painted-geometric & Late archaic & \\
\hline K 21972 & Hydria/amphora & Painted-geometric & First half sixth century BC & \\
\hline K 21979 & Closed form & Painted-geometric & First half sixth century BC & \\
\hline K 21998 & Bowl & Painted-geometric & First half sixth century BC & \\
\hline K 22010 & Bowl & Painted-geometric & First half sixth century BC & \\
\hline K 22031 & Bowl & Painted-geometric & First half sixth century BC & \\
\hline K 22086 & Bowl & Painted-geometric & First half sixth century BC & \\
\hline K 22089 & Basin & Painted-geometric & First half sixth century BC & \\
\hline K 22091 B & Jug & Painted-geometric & First half sixth century BC & \\
\hline K 22110 & Hydria/amphora & Painted-geometric & First half sixth century BC & \\
\hline K 22112 & Jug & Painted-geometric & First half sixth century BC & \\
\hline K 22113 & Hydria/amphora & Painted-geometric & First half sixth century BC & \\
\hline K 22124 & Bowl & Painted-geometric & First half sixth century BC & \\
\hline K 22125 & Bowl & Painted-geometric & First half sixth century BC & \\
\hline K 22126 & Bowl & Painted-geometric & First half sixth century BC & \\
\hline K 22127 & Hydria/amphora & Painted-geometric & First half sixth century BC & \\
\hline K 22141 B & Bowl & Incised-geometric & First half sixth century BC & \\
\hline K 22142 & Closed form & Incised-geometric & First half sixth century BC & \\
\hline K 22146 & Bowl & Painted & First half sixth century BC & \\
\hline K 22147 & Bowl & Painted & First half sixth century BC & \\
\hline K 22160 & Bowl & Painted-geometric & First half sixth century BC & \\
\hline K 22163 & Basin & Painted & First half sixth century BC & \\
\hline K 22168 & Basin & Painted & First half sixth century BC & \\
\hline K 22169 & Basin & Painted & First half sixth century BC & \\
\hline K 22253 & Bowl & Painted-geometric & First half sixth century BC & \\
\hline K 22255 & Bowl & Incised-geometric & First half sixth century BC & \\
\hline K 22256 & Cup & Painted-geometric & First half sixth century BC & \\
\hline K 22259 B & Cup & Painted-geometric & First half sixth century BC & \\
\hline K $22271 \mathrm{~A}$ & Bowl & Incised-geometric & First half sixth century BC & \\
\hline K 22288 & Cup & Painted-geometric & First half sixth century BC & \\
\hline K 22705 D & Jug & Painted-geometric & Late archaic & \\
\hline K 22912 & Three-lobed jug & Painted-geometric & Late archaic & \\
\hline K 23361 & Bowl & Painted-geometric & Late archaic & \\
\hline K 23761 B & Crater & Painted-geometric & Late archaic & \\
\hline K 24011 & Ladle & Incised-geometric & Late archaic & \\
\hline K 24418 & Bowl & Painted-geometric & Late archaic & \\
\hline K 24509 A & Crater & Painted/incised-geometric & Late archaic & \\
\hline K 24635 & Bowl & Painted/incised-geometric & Late archaic & \\
\hline K 24640 & Hydria/amphora & Painted-geometric & Late archaic & \\
\hline K 26018 & Ladle & Incised-geometric & Late archaic & \\
\hline K 26020 & Crater & Painted-geometric & Late archaic & \\
\hline K 26131 B & Hydria/amphora & Painted-geometric & Late archaic & \\
\hline K 27968 & Basin & Painted & First half sixth century $B C$ & \\
\hline K 28424 & Hydria/amphora & Painted-geometric & First half sixth century BC & \\
\hline
\end{tabular}


Fig. 5 Compilation of the forms of the ceramic samples of mattpainted Archaic indigenous pottery (first half of the sixth to first half of the fifth century BC) recovered on Monte Iato

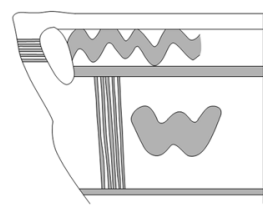

K10769 B krater
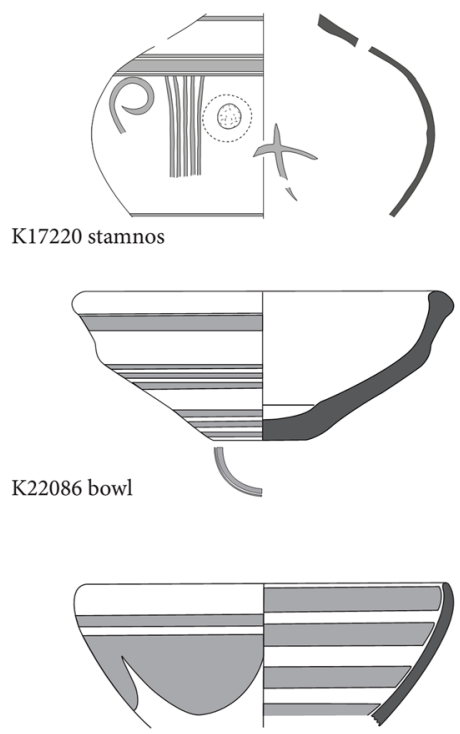

K22256 cup

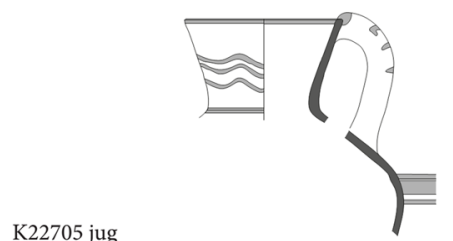

K22705 jug

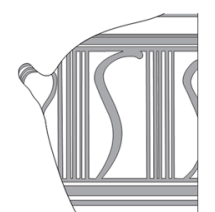

K26131 A/B hydria/amphora

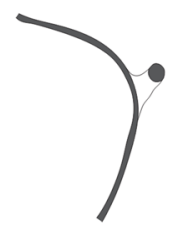

4
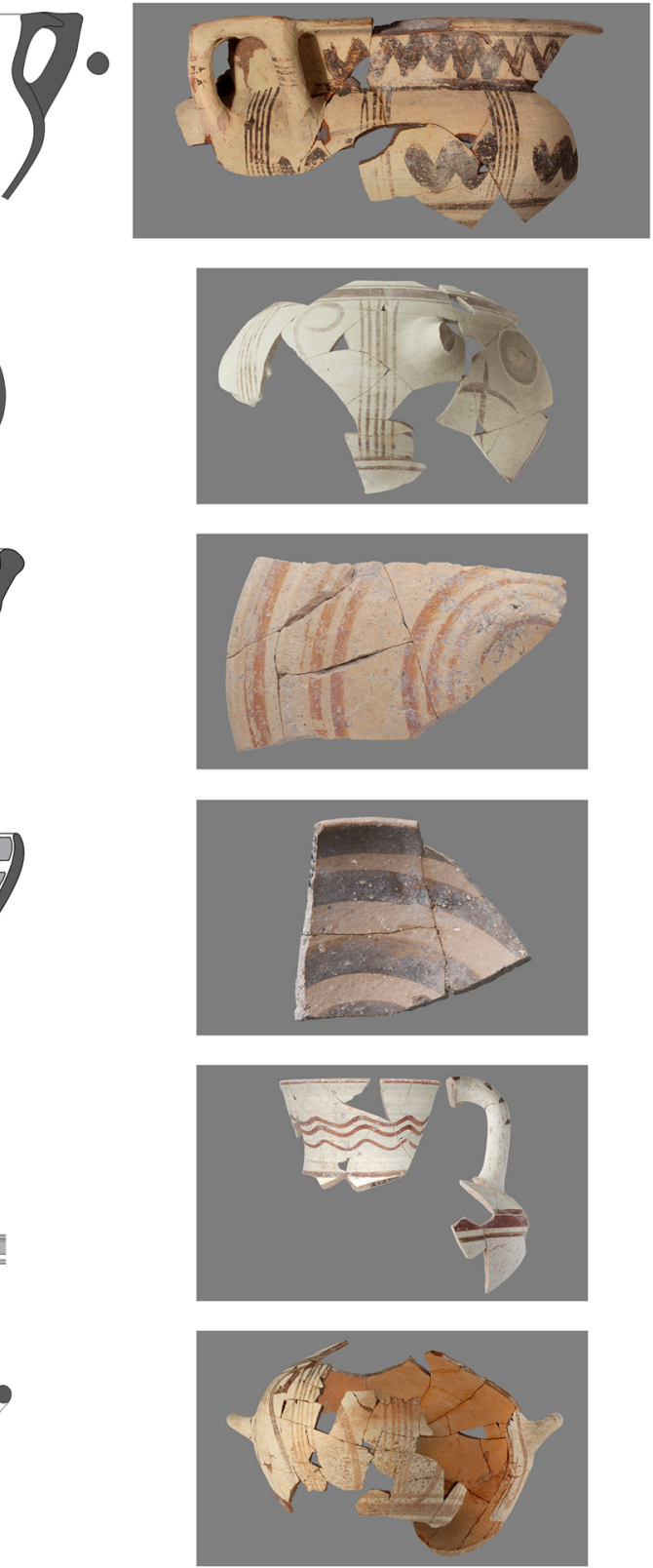

Ontiveros et al. (2004). The data set also included 11 selected chemical variables $\left(\mathrm{SiO}_{2}, \mathrm{CaO}, \mathrm{Fe}_{2} \mathrm{O}_{3}, \mathrm{Al}_{2} \mathrm{O}_{3}, \mathrm{~K}_{2} \mathrm{O}, \mathrm{TiO}_{2}, \mathrm{~V}\right.$, $\mathrm{Zr}, \mathrm{Ba}, \mathrm{Sr}, \mathrm{Nb}$ ) using S-plus software (MathSoft, Inc.).

The bulk chemical compositions were determined using the fusion inductively coupled plasma optical emission spectrometry (ICP-OES) technique for the major oxides and inductively coupled plasma mass spectrometry (ICP-MS) for trace elements by Activation Laboratories Ltd. (Ontario, Canada). The samples were first air-dried, ground and homogenized in a planetary agate ball-mill (Retsch PM100) and then prepared and analysed in a batch system. Each batch contained a method reagent blank, certified reference materials and some replicates. Samples were mixed with a flux of lithium metaborate and lithium tetraborate and fused in an induction furnace. The molten melt was immediately poured into a solution of $5 \%$ nitric acid containing an internal standard until completely dissolved. The samples were run for major oxides and selected trace elements on a combination simultaneous/sequential Thermo Jarrell-Ash ENVIRO II ICP or a Varian Vista 735 ICP. Calibration was performed using seven prepared USGS and CANMET certified reference materials. One of the seven standards was used during the analysis for every group of ten samples. Fifty-six elements were here considered (with detection limits in brackets): $\mathrm{Na}(0.01)$, $\mathrm{Mg}$ (0.01), Al (0.01), Si (0.01), P (0.01), K (0.01), Ca (0.01), $\mathrm{Ti}(0.001)$, Mn (0.001) and $\mathrm{Fe}(0.01)$, given as oxides (mass\%), and $\mathrm{Cr}(20), \mathrm{V}(5), \mathrm{Cu}(10), \mathrm{Zn}(30), \mathrm{Rb}(2), \mathrm{Sr}$ (2), Y (1), Zr (4), Ba (3), Pb (5), Ce (0.1), Nb (1), La (0.1), 
Sc (1), Be (1), V (5), Y (2), Co (1), Ga (1), Ge (1), As (5), Mo (2), Ag (0.5), In (0.2), Sn (1), Sb (0.5), Cs (0.5), Pr (0.05), Nd (0.1), Sm (0.1), Eu (0.05), Gd (0.1), Tb (0.1), Dy (0.1), Ho (0.1), Er (0.1), Tm (0.05), Yb (0.1), Lu (0.04), Hf (0.2), Ta (0.1), W (1), Tl (0.1), Bi (0.4), Th (0.1), U (0.1) and Ni (20), given as element (ppm). The results for the major element oxides were recalculated on an LOI-free basis.

\section{Results and discussion}

\section{Local raw clays}

The results of the granulometric analysis of the local raw clays are presented in Fig. 6A-B. In this graph, the percentages by weight of the granulometric classes of the individuals and Shepard's classification diagram (Shepard 1954) are represented. It is worth noting that while the representative samples of the Tavernola Formation and the Marne di San Cipirello Formation are mostly silty clays, the samples representative of the local outcrops of the Terravecchia Formation can be classified as clayey silt. In these latter materials, the content of silt particles (i.e. particles with a diameter of $0.002-0.063 \mathrm{~mm}$ ) is by far higher than the clay ones $(<0.002 \mathrm{~mm})$, up to a maximum of $63 \%$ by weight. Concerning the sand-sized granule content, the deposits of the Tavernola Formation have only modest amounts, ranging between 6 and $10 \%$ by weight, while in the deposits from the Terravecchia Formation, they are distinctly lower ( $13 \%$ by weight). On the other hand, the sand-sized fraction measured in the deposits of the Marne di San Cipirello Formation is relatively greater, ranging between
11 and $16 \%$ by weight. Therefore, it is possible to state that based on these data and strictly from the point of view of grain-size distribution, the three raw materials present in the territory under study can be considered suitable for brick and pottery production.

The textural characteristics and the mineralogicalpetrographic nature of the aplastic inclusions were identified on experimental briquettes fired at $900{ }^{\circ} \mathrm{C}$ made from the natural clayey raw materials. The clays of Tavernola Formation showed a quite uniform distribution of natural aplastic inclusions, with packing ranging around 10-12\% (area) under the polarizing microscope. The size classes of coarse silt $(0.04-0.06 \mathrm{~mm})$ and very fine sand $(0.06-0.125$ $\mathrm{mm})$ prevailed. Granules falling in the fine sand class $(0.125-0.25 \mathrm{~mm})$ were sporadic, while coarser grains were even rarer $(>0.5 \mathrm{~mm})$.

Regarding the mineralogical composition (Fig. 7A-B), the sandy skeleton was primarily composed of angular to subangular monocrystalline quartz grains. Common to sporadic polycrystalline quartz and tiny mica flakes were disseminated in the plastic groundmass. K-feldspar, plagioclase, chert, glauconite and quartzarenite lithic fragments were sporadic to rare. The calcareous component, consisting of bioclasts mostly decomposed by the firing process, was sporadic to rare. The groundmass showed no optical activity, it was quite homogeneous in texture (rare lumps), and pores (mostly irregular in shape) were less than 10\% (area).

The average abundance of the aplastic inclusions (packing) in the Marne di San Cipirello Formation was around 15\% (area), with the exception of the CIP 7 sample, which was relatively higher than the others $(20 \%)$. The grain-size

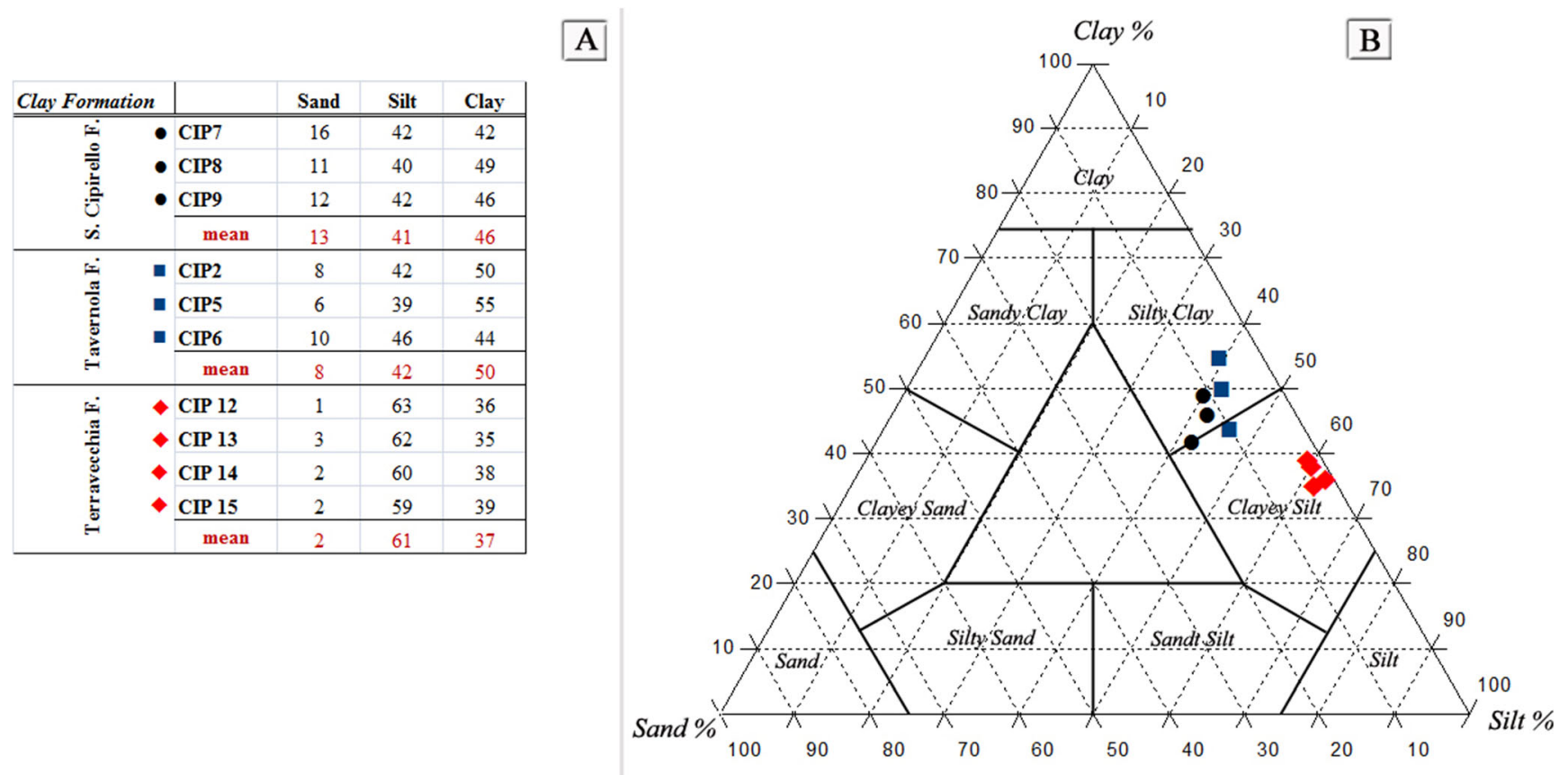

Fig. 6 A Results of grain-size analysis of local clayey raw materials. B Data set plotting in the Shepard's classification diagram (after Shepard 1954) 
Fig. 7 Thin-section microphotographs of the experimentally fired clay materials $\left(900{ }^{\circ} \mathrm{C}\right)$ by the polarizing microscope. A-B Tavernola Formation, samples Cip2 and Cip5 (crossed nicols, scale bar $=0.5 \mathrm{~mm})$; C-D Marne di San Cipirello Formation, samples Cip7 and Cip9 (crossed nicols, scale bar $=0.5 \mathrm{~mm}) ; \mathbf{E}-\mathbf{F}$ Terravecchia Formation, samples Cip14 and Cip12 (crossed nicols, scale bar $=0.5 \mathrm{~mm})$
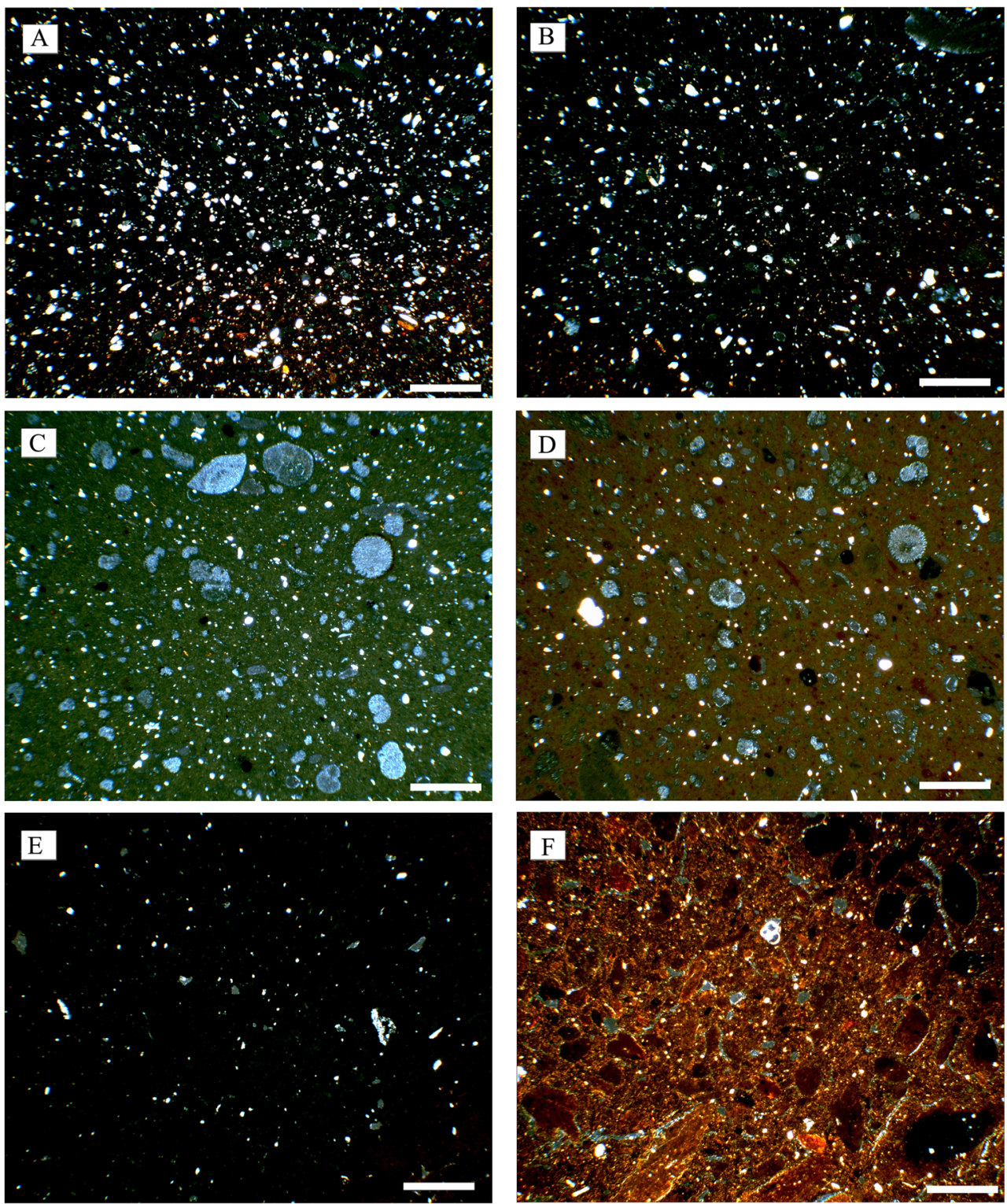

distribution ranged mainly between coarse silt $(0.04-0.06$ $\mathrm{mm})$ and medium sand $(0.25-0.5 \mathrm{~mm})$. Inclusions of coarsesized sand $(0.5-1 \mathrm{~mm})$ were sporadic to rare. From the compositional point of view, calcareous bioclasts evidently prevailed (planktonic foraminifers such as Orbulina, Globorotalia, Paragloborotalia, Globigerinoides), more often showing apparent signs of thermal decomposition (experimental firing up to $900{ }^{\circ} \mathrm{C}$ ). Relatively much more common subordinate constituents were the monocrystalline quartz granules (from angular to subangular) and K-feldspar. Rare constituents were tiny mica flakes, polycrystalline quartz and chert (Fig. 7C-D).

The clayey materials taken from the Terravecchia Formation (Fig.7E-F) showed very poor aplastic inclusions (low packing) estimated at no more than 1-3\% (area). The aplastic grains were very poor and primarily fell into the classes of coarse silt $(0.04-0.06 \mathrm{~mm})$ and very fine sand $(0.06-0.125 \mathrm{~mm})$. Fine sand grains $(0.125-0.25 \mathrm{~mm})$ were rarely found. The main component was monocrystalline quartz (with grains from angular to subangular). Tiny mica flakes (rarely more than $0.1 \mathrm{~mm}$ in the direction of elongation) were common constituents, scattered in the plastic groundmass. Sporadic components were feldspars (plagioclase and $\mathrm{K}$-feldspar), polycrystalline quartz, chert and opaque minerals. The calcareous component was sporadic to rare, denoted only by pore casts and micritic clots produced by the complete thermal decomposition of calcareous microfossils after the experimental firing at $900{ }^{\circ} \mathrm{C}$ (for details, see Cau Ontiveros et al. 2002).

The chemical analysis of the raw materials highlights the differences in $\mathrm{SiO}_{2} / \mathrm{CaO}$ ratios, which agrees with the macroscopic observations. The clays of Tavernola Formation and 
Terravecchia Formation had a $60 \%$ per weight average concentration of $\mathrm{SiO}_{2}$. The Terravecchia Formation also showed significantly higher $\mathrm{Al}_{2} \mathrm{O}_{3}$ (up to $23.17 \mathrm{wt} \%$ ) and $\mathrm{Fe}_{2} \mathrm{O}_{3}(9.36$ wt $\%$ ) average values than the clays of Marne di San Cipirello Formation (respectively: $40.36 \mathrm{wt} \%$ for $\mathrm{SiO}_{2}, 14.86 \mathrm{wt} \%$ for $\mathrm{Al}_{2} \mathrm{O}_{3}$ and $6.05 \mathrm{wt} \%$ for $\mathrm{Fe}_{2} \mathrm{O}_{3}$ ), which, on the other hand, was characterized by $\mathrm{CaO}$ contents on average around $33 \%$ by weight, which was higher than the average values of the other clayey deposits present in the area under study (Table 4 and Fig. 8A-B).

The remaining major elements such as $\mathrm{MgO}, \mathrm{K}_{2} \mathrm{O}, \mathrm{Na}_{2} \mathrm{O}$ and $\mathrm{TiO}_{2}$ showed less standard deviation in Tavernola and Terravecchia Formations and higher average concentrations than the Marne di San Cipirello Formation, they were always higher than those of the Marne di San Cipirello Formation, while the trace elements for the raw materials coming from the Marne di San Cipirello deposits were lower except for $\mathrm{Sr}$ (geochemically related to $\mathrm{Ca}$ ). The raw clays from the Tavernola and Terravecchia Formations were however distinguishable for higher average concentrations of transition metals (V, Cr, Co, Ni, Cu, Zn) and $\mathrm{Ba}$ and $\mathrm{Rb}$ (correlated to the feldspar and mica content) and rare earth elements such as $\mathrm{La}$ and $\mathrm{Ce}$, but differences in $\mathrm{Zr}, \mathrm{Nb}$ and $\mathrm{Y}$ can be observed too. The concentration of the rest of the analysed trace elements was too low to use them as markers to discriminate origin (Table 4 and Fig. 8C-8D).

The petrochemical results showed that the clay deposits available in the vicinity of the Archaic site of Monte Iato were suitable for ceramic production and the deposits from which they come could be distinguished, both on a petrographic and a chemical basis. The most distinctive component was the content of calcareous microfossils which was much lower in the Tavernola and Terravecchia Formations, while the quantities of siliciclastic sand inclusions were higher than the Marne di San Cipirello deposits. The clayey deposits that outcrop in the Terravecchia Formation could be defined as "ball clay" poor in fine detritic sand and low $\mathrm{CaO}$.

\section{Local traditional tiles and bricks}

The petrographic analysis of thin sections by polarizing microscope allowed the identification of different fabrics in the traditional bricks and tiles produced in the old ceramic kilns of San Giuseppe Iato and San Cipirello (20 representative samples).

The identified fabrics could be differentiated according to the compositional and textural features of the aplastic inclusions (mineralogy, packing and grain-size distribution). In general, the analysed ceramic artefacts were compatible with highly calcareous clay probably related to the Marne di San Cipirello Formation and the mixing and/or tempering that involved the same clayey raw materials. Up to 19 of the 20 analysed samples could be distributed into four petrographic subgroups, which were based on the relative mixing proportion between the Marne di San Cipirello clays and the other local raw clays (both characterized by scarce calcareous components and comparatively more abundant siliciclastic inclusions). The sample labelled SCP14 was solely characterized by a paste resulting from abundant tempering of the San Cipirello marly clays with coarse siliciclastic sand (0.5-2 $\mathrm{mm}$ ), clearly deriving from the local sandy member of the Terravecchia Formation unit. Nevertheless, these types of ceramic pastes do not seem to be related to specific functionalities of any ceramic building material. Nor do they seem to be related to different production periods or different kiln sites (workshops). The compositional differences might be a simple consequence of the exploitation of different supply points, because the intra-source variability in the above-mentioned geological deposits was not clear due to the recent geomorphologic evolution of the territory. The analysed material could therefore be classified into various sub-fabrics.

The sub-fabric named Mix-I (samples: SCP 1, SCP 2, SCP 3, SCP 12, SCP 15, SCP 17, SCP 18) showed an optically inactive groundmass, with a distinctly non-homogeneous structure (frequent clay lumps). The abundance of siliceous aplastic grains varied from 3 to $5 \%$ (area). Packing increased up to the $20-25 \%$ area considering also the calcareous components. Aplastic inclusions with sizes ranging between coarse silt $(0.04-0.06 \mathrm{~mm})$ and very fine sand $(0.06-0.125$ $\mathrm{mm})$ were prevalent. Fine sand $(0.125-0.25 \mathrm{~mm})$ and medium sand $(0.25-0.5 \mathrm{~mm})$ inclusions were subordinate to rare. Calcareous bioclasts (planktonic and benthic microfossils) were the predominant constituents, very often showing signs of incipient thermal decomposition (Fig. 9A-B). In this latter case, they could also be represented by micritic clots or rounded/subrounded pore casts with sizes mainly between 0.2 and $0.4 \mathrm{~mm}$. More subordinate constituents were monocrystalline quartz grains (from angular to subangular in shape), K-feldspar, polycrystalline quartz and quartzarenite fragments.

The sub-fabric named Mix-II (samples: SCP 13, SCP 16, SCP 19, SCP 20) was characterized by an optically inactive groundmass with numerous clay lumps. The abundance of siliceous aplastic inclusions was around 10\% (area). From the point of view of grain-size distribution, the inclusions in the classes of coarse silt $(0.04-0.06 \mathrm{~mm})$, fine sand $(0.125-$ $0.25 \mathrm{~mm})$ and very fine $(0.06-0.125 \mathrm{~mm})$ were prevalent. Medium-coarse sand was relatively subordinate. Also, in this petrographic subgroup, the calcareous component (bioclasts, micritic clots, decomposition pore casts) prevailed over the siliciclastic component represented by monocrystalline quartz, polycrystalline quartz, quartzarenite fragments and K-feldspar (Fig. 9C).

The sub-fabric named Mix-III (samples: SCP4, SCP7, SCP9, SCP10, SCP11) showed an optically inactive groundmass with a distinctly non-homogeneous structure and 
Table 4 Chemical composition of raw clays (major elements by weight $\%$ and trace elements by ppm)

\begin{tabular}{|c|c|c|c|c|c|c|c|c|c|c|c|c|c|c|}
\hline \multirow[t]{2}{*}{ Clay } & & \multicolumn{4}{|c|}{ Tavernola $F$. } & \multicolumn{5}{|c|}{ Terravecchia F. } & \multicolumn{4}{|c|}{ Marne S. Cipirello F. } \\
\hline & & CIP 2 & CIP 5 & CIP 6 & Mean & CIP 12 & CIP 13 & CIP 14 & CIP 15 & Mean & CIP 7 & CIP 8 & CIP 9 & Mean \\
\hline $\mathrm{SiO}_{2}$ & $w t \%$ & 62.11 & 60.15 & 64.45 & 62.24 & 57.82 & 57.88 & 57.72 & 56.66 & 57.52 & 38.83 & 40.68 & 41.57 & 40.36 \\
\hline $\mathrm{Al}_{2} \mathbf{O}_{3}$ & $w t \%$ & 16.98 & 18.21 & 17.47 & 17.55 & 21.96 & 23.16 & 23.11 & 24.46 & 23.17 & 12.65 & 16.65 & 15.27 & 14.86 \\
\hline $\mathrm{Fe}_{2} \mathrm{O}_{3}(\mathrm{~T})$ & $w t \%$ & 7.11 & 7.19 & 7.57 & 7.29 & 9.52 & 9.31 & 9.12 & 9.48 & 9.36 & 5.22 & 6.61 & 6.31 & 6.05 \\
\hline MnO & $w t \%$ & 0.05 & 0.04 & 0.05 & 0.05 & 0.09 & 0.07 & 0.09 & 0.11 & 0.09 & 0.05 & 0.08 & 0.08 & 0.07 \\
\hline MgO & $w t \%$ & 2.27 & 2.9 & 2.29 & 2.49 & 2.32 & 2.24 & 2.34 & 2.19 & 2.27 & 1.81 & 2.23 & 1.76 & 1.93 \\
\hline $\mathrm{CaO}$ & $w t \%$ & 7.64 & 7.72 & 3.83 & 6.40 & 4.45 & 3.55 & 3.87 & 3.15 & 3.76 & 38.63 & 30.48 & 32.11 & 33.74 \\
\hline $\mathrm{Na}_{2} \mathrm{O}$ & $w t \%$ & 0.49 & 0.35 & 0.75 & 0.53 & 0.26 & 0.27 & 0.27 & 0.33 & 0.28 & 0.23 & 0.22 & 0.21 & 0.22 \\
\hline $\mathbf{K}_{2} \mathbf{O}$ & $w t \%$ & 2.28 & 2.32 & 2.41 & 2.34 & 2.45 & 2.44 & 2.41 & 2.51 & 2.45 & 1.73 & 2.01 & 1.74 & 1.83 \\
\hline $\mathrm{TiO}_{2}$ & $w t \%$ & 0.88 & 0.93 & 0.96 & 0.92 & 0.96 & 0.98 & 0.96 & 1 & 0.98 & 0.56 & 0.81 & 0.74 & 0.70 \\
\hline $\mathbf{P}_{2} \mathbf{O}_{5}$ & $w t \%$ & 0.19 & 0.19 & 0.22 & 0.20 & 0.17 & 0.1 & 0.11 & 0.11 & 0.12 & 0.29 & 0.23 & 0.21 & 0.24 \\
\hline Sc & ppm & 13 & 13 & 13 & 13.00 & 16 & 16 & 16 & 16 & 16 & 8 & 12 & 11 & 10 \\
\hline $\mathrm{Be}$ & ppm & 2 & 3 & 3 & 2.67 & 3 & 3 & 3 & 3 & 3 & 2 & 2 & 2 & 2 \\
\hline $\mathbf{V}$ & ppm & 132 & 135 & 139 & 135.33 & 149 & 147 & 148 & 207 & 163 & 90 & 126 & 110 & 109 \\
\hline $\mathbf{B a}$ & ppm & 314 & 277 & 246 & 279.00 & 309 & 238 & 225 & 377 & 287 & 186 & 235 & 226 & 216 \\
\hline $\mathrm{Sr}$ & ppm & 235 & 237 & 194 & 222.00 & 248 & 214 & 223 & 210 & 224 & 722 & 534 & 544 & 600 \\
\hline $\mathbf{Y}$ & ppm & 24 & 23 & 26 & 24.33 & 25 & 23 & 25 & 25 & 25 & 15 & 20 & 18 & 18 \\
\hline $\mathrm{Zr}$ & ppm & 211 & 178 & 233 & 207.33 & 144 & 148 & 146 & 145 & 146 & 98 & 137 & 118 & 118 \\
\hline $\mathrm{Cr}$ & ppm & 100 & 90 & 100 & 96.67 & 110 & 100 & 110 & 110 & 108 & 60 & 90 & 80 & 77 \\
\hline Co & ppm & 10 & 11 & 13 & 11.33 & 17 & 17 & 18 & 29 & 20 & 8 & 13 & 11 & 11 \\
\hline $\mathbf{N i}$ & ppm & 30 & 30 & 30 & 30.00 & 40 & 40 & 40 & 70 & 48 & 30 & 40 & 40 & 37 \\
\hline $\mathrm{Cu}$ & ppm & 20 & 20 & 20 & 20.00 & 30 & 30 & 30 & 30 & 30 & 20 & 20 & 20 & 20 \\
\hline Zn & ppm & 130 & 100 & 100 & 110.00 & 150 & 140 & 160 & 180 & 158 & 70 & 90 & 80 & 80 \\
\hline Ga & ppm & 21 & 21 & 23 & 21.67 & 25 & 27 & 27 & 28 & 27 & 14 & 18 & 16 & 16 \\
\hline $\mathbf{G e}$ & ppm & 2 & 2 & 2 & 2.00 & 2 & 2 & 2 & 2 & 2 & 1 & 2 & 1 & 1 \\
\hline As & ppm & 8 & $<5$ & 6 & 7.00 & 5 & 8 & $<5$ & 8 & 7 & $<5$ & $<5$ & $<5$ & \\
\hline $\mathbf{R b}$ & ppm & 93 & 92 & 97 & 94.00 & 90 & 91 & 93 & 94 & 92 & 60 & 78 & 68 & 69 \\
\hline $\mathbf{N b}$ & ppm & 16 & 15 & 19 & 16.67 & 17 & 17 & 18 & 19 & 18 & 8 & 13 & 11 & 11 \\
\hline Mo & ppm & $<2$ & $<2$ & $<2$ & & $<2$ & 2 & $<2$ & $<2$ & & $<2$ & $<2$ & $<2$ & \\
\hline Ag & ppm & 2.8 & 1.8 & 2.3 & 2.30 & 1.2 & 1.8 & 1.9 & 1.7 & 2 & 1.1 & 1.6 & 1.5 & 1 \\
\hline In & ppm & $<0.2$ & $<0.2$ & $<0.2$ & & $<0.2$ & $<0.2$ & $<0.2$ & $<0.2$ & & $<0.2$ & $<0.2$ & $<0.2$ & \\
\hline Sn & ppm & $<1$ & $<1$ & $<1$ & & 2 & $<1$ & 1 & $<1$ & 2 & $<1$ & $<1$ & $<1$ & \\
\hline Sb & ppm & 0.6 & $<0.5$ & $<0.5$ & 0.60 & 0.7 & 0.5 & 0.6 & 1.1 & 1 & $<0.5$ & $<0.5$ & $<0.5$ & \\
\hline Cs & ppm & 5.3 & 5.5 & 5.6 & 5.47 & 6.6 & 6.2 & 6.6 & 5.9 & 6 & 3.3 & 4.9 & 4.3 & 4 \\
\hline $\mathbf{L a}$ & ppm & 38.9 & 37.8 & 41.8 & 39.50 & 49.8 & 46.6 & 50.2 & 55.1 & 50 & 31.7 & 34.1 & 31.1 & 32 \\
\hline $\mathrm{Ce}$ & ppm & 79.5 & 75.9 & 86.7 & 80.70 & 101 & 98.6 & 109 & 114 & 106 & 58.4 & 68.3 & 61.3 & 63 \\
\hline Pr & ppm & 8.59 & 8.38 & 9.38 & 8.78 & 11.4 & 10.3 & 11.2 & 11.9 & 11 & 5.62 & 7.23 & 6.61 & 6 \\
\hline Nd & ppm & 33.5 & 31.6 & 36.2 & 33.77 & 41.6 & 39.2 & 42.3 & 44.6 & 42 & 20.2 & 26.9 & 25.5 & 24 \\
\hline Sm & ppm & 6 & 5.9 & 7 & 6.30 & 7.7 & 7.5 & 8.4 & 8.5 & 8 & 4.2 & 5.2 & 4.7 & 5 \\
\hline $\mathbf{E u}$ & ppm & 1.31 & 1.29 & 1.51 & 1.37 & 1.68 & 1.57 & 1.73 & 1.78 & 2 & 0.93 & 1.1 & 1.06 & 1 \\
\hline Gd & ppm & 6 & 5.5 & 6.3 & 5.93 & 6.4 & 6.4 & 7.4 & 7.4 & 7 & 3.8 & 4.7 & 4.5 & 4 \\
\hline $\mathbf{T b}$ & ppm & 0.9 & 0.8 & 0.9 & 0.87 & 1 & 0.9 & 1.1 & 1 & 1 & 0.5 & 0.7 & 0.6 & 1 \\
\hline Dy & ppm & 4.7 & 4.3 & 5.2 & 4.73 & 5.3 & 4.9 & 5.5 & 5.6 & 5 & 3 & 3.7 & 3.5 & 3 \\
\hline Но & ppm & 0.9 & 0.8 & 1 & 0.90 & 1 & 0.9 & 1 & 1.1 & 1 & 0.5 & 0.7 & 0.7 & 1 \\
\hline $\mathbf{E r}$ & ppm & 2.7 & 2.4 & 2.9 & 2.67 & 2.7 & 2.7 & 2.8 & 2.9 & 3 & 1.4 & 2 & 1.9 & 2 \\
\hline $\mathbf{T m}$ & ppm & 0.4 & 0.35 & 0.42 & 0.39 & 0.39 & 0.4 & 0.42 & 0.42 & 0 & 0.21 & 0.3 & 0.29 & 0 \\
\hline Yb & ppm & 2.6 & 2.3 & 2.7 & 2.53 & 2.5 & 2.6 & 2.7 & 2.8 & 3 & 1.4 & 2 & 1.9 & 2 \\
\hline $\mathbf{L u}$ & ppm & 0.42 & 0.39 & 0.43 & 0.41 & 0.4 & 0.41 & 0.43 & 0.43 & 0 & 0.22 & 0.31 & 0.3 & 0 \\
\hline
\end{tabular}


Table 4 (continued)

\begin{tabular}{|c|c|c|c|c|c|c|c|c|c|c|c|c|c|c|}
\hline \multirow[t]{2}{*}{ Clay } & & \multicolumn{4}{|c|}{ Tavernola $F$. } & \multicolumn{5}{|c|}{ Terravecchia F. } & \multicolumn{4}{|c|}{ Marne S. Cipirello F. } \\
\hline & & CIP 2 & CIP 5 & CIP 6 & Mean & CIP 12 & CIP 13 & CIP 14 & CIP 15 & Mean & CIP 7 & CIP 8 & CIP 9 & Mean \\
\hline Hf & ppm & 5.5 & 4.5 & 5.8 & 5.27 & 3.9 & 4.2 & 3.9 & 3.7 & 4 & 1.9 & 3.4 & 3.2 & 3 \\
\hline Ta & ppm & 1.2 & 1.1 & 1.3 & 1.20 & 1.3 & 1.3 & 1.4 & 1.4 & 1 & 0.7 & 1 & 0.8 & 1 \\
\hline $\mathbf{W}$ & ppm & $<1$ & $<1$ & $<1$ & & 1 & 1 & $<1$ & $<1$ & 1 & $<1$ & $<1$ & $<1$ & \\
\hline $\mathbf{T l}$ & ppm & 0.4 & 0.4 & 0.4 & 0.40 & 0.4 & 0.5 & 0.5 & 0.5 & 0 & 0.3 & 0.3 & 0.3 & 0 \\
\hline $\mathbf{P b}$ & ppm & 19 & 16 & 16 & 17.00 & 20 & 21 & 17 & 18 & 19 & 15 & 16 & 15 & 15 \\
\hline $\mathbf{B i}$ & ppm & $<0.4$ & $<0.4$ & $<0.4$ & & $<0.4$ & $<0.4$ & $<0.4$ & $<0.4$ & & $<0.4$ & $<0.4$ & $<0.4$ & \\
\hline Th & ppm & 11.7 & 10.8 & 12.3 & 11.60 & 12.8 & 13.3 & 13.7 & 14.7 & 14 & 7.2 & 9.3 & 8.3 & 8 \\
\hline $\mathbf{U}$ & ppm & 2.8 & 2.7 & 2.7 & 2.73 & 2.8 & 2.8 & 3.1 & 2.4 & 3 & 2.2 & 2.4 & 2.3 & 2 \\
\hline
\end{tabular}

numerous clay lumps. Aplastic inclusion abundance was slightly greater than Mix-II if referring only to siliciclastic components $(10-15 \%$ area). Medium sand $(0.25-0.5 \mathrm{~mm})$ and fine sand $(0.125-0.25 \mathrm{~mm})$ were relatively better represented than all of the other granulometric classes. Concerning composition, monocrystalline quartz and calcareous bioclasts (more or less affected by the firing process) were approximately equivalent in abundance. Polycrystalline quartz, K-feldspar and quartzarenite fragments were sporadically detected (Fig. 9D).

The sub-fabric labelled Mix-IV (samples: SCP5, SCP6, SCP8), as noted in the other petrographic subgroups, was characterized by a non-birefringent groundmass and frequent clay lumps. Aplastic grains abundance (siliciclastic

D Terravecchia F.; $\bigcirc$ Marne S. Cipirello F.; $\diamond$ Tavernola F.
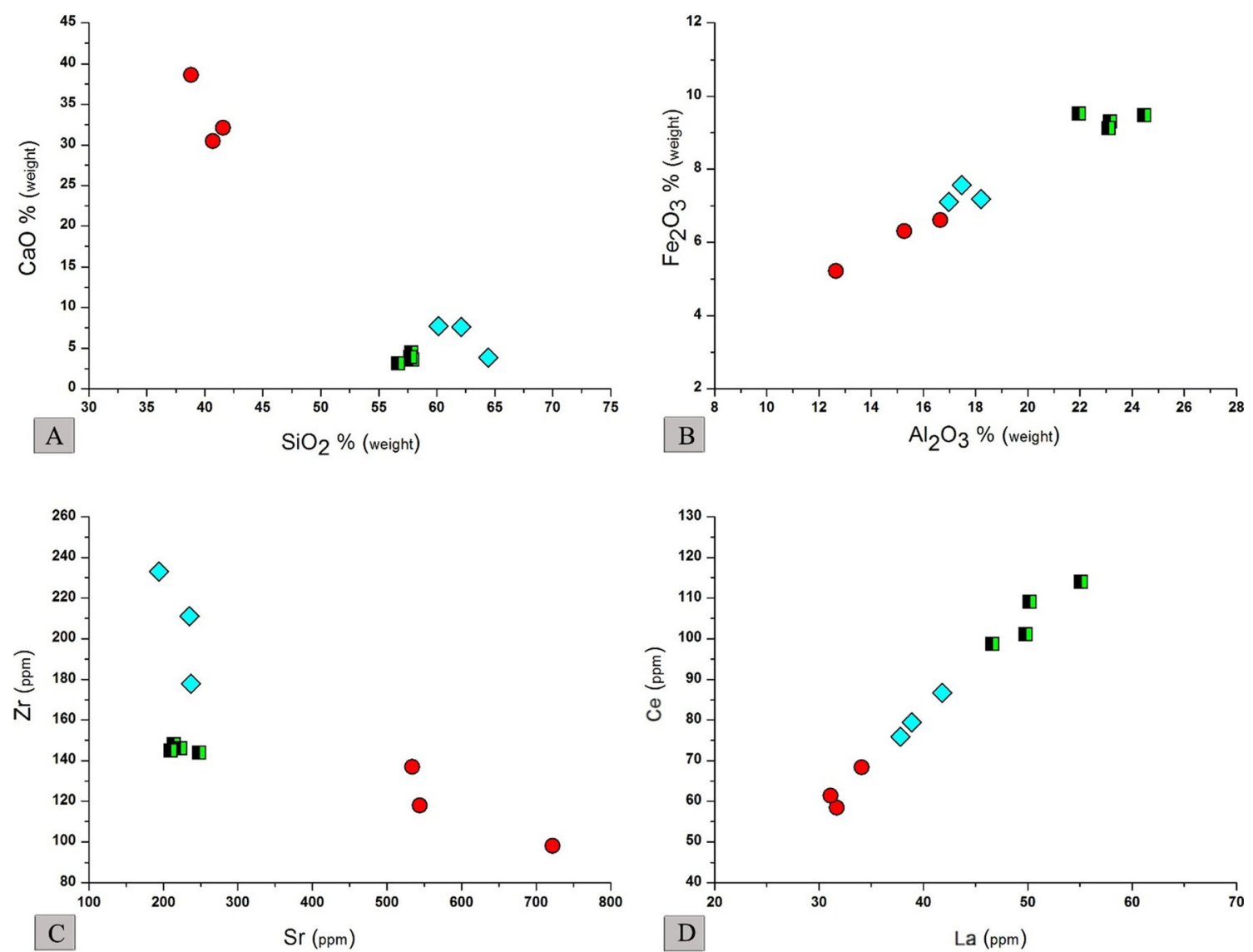

Fig. 8 Scatter plots $\mathrm{SiO}_{2}-\mathrm{CaO}(\mathbf{A}), \mathrm{Al}_{2} \mathrm{O}_{3}-\mathrm{Fe}_{2} \mathrm{O}_{3}(\mathbf{B}), \mathrm{Sr}-\mathrm{Zr}(\mathbf{C})$ and $\mathrm{La}-\mathrm{Ce}$ (D) showing a clear difference in chemical composition of the local raw materials based on major and trace elements 
Fig. 9 Thin-section

microphotographs of the local old traditional tiles and bricks by the polarizing microscope. A-B paste subgroup Mix-I (left, sample $\mathrm{SCP} 3$, crossed nicol, scale bar = 0.5 ; right, sample SCP3; crossed nicol, scale bar $=0.2 \mathrm{~mm}$ ); $\mathbf{C}$ paste subgroup Mix-II (sample SCP16; crossed nicol, scale bar = $0.5 \mathrm{~mm}$ ); D paste subgroup MixIII (sample SCP4; crossed nicol, scale bar $=0.5 \mathrm{~mm})$; $\mathbf{E}$ paste subgroup Mix-IV (sample SCP5; crossed nicol, scale bar $=0.5$ $\mathrm{mm}$ ); F single SCP14 (crossed nicol, scale bar $=0.5 \mathrm{~mm}$ )
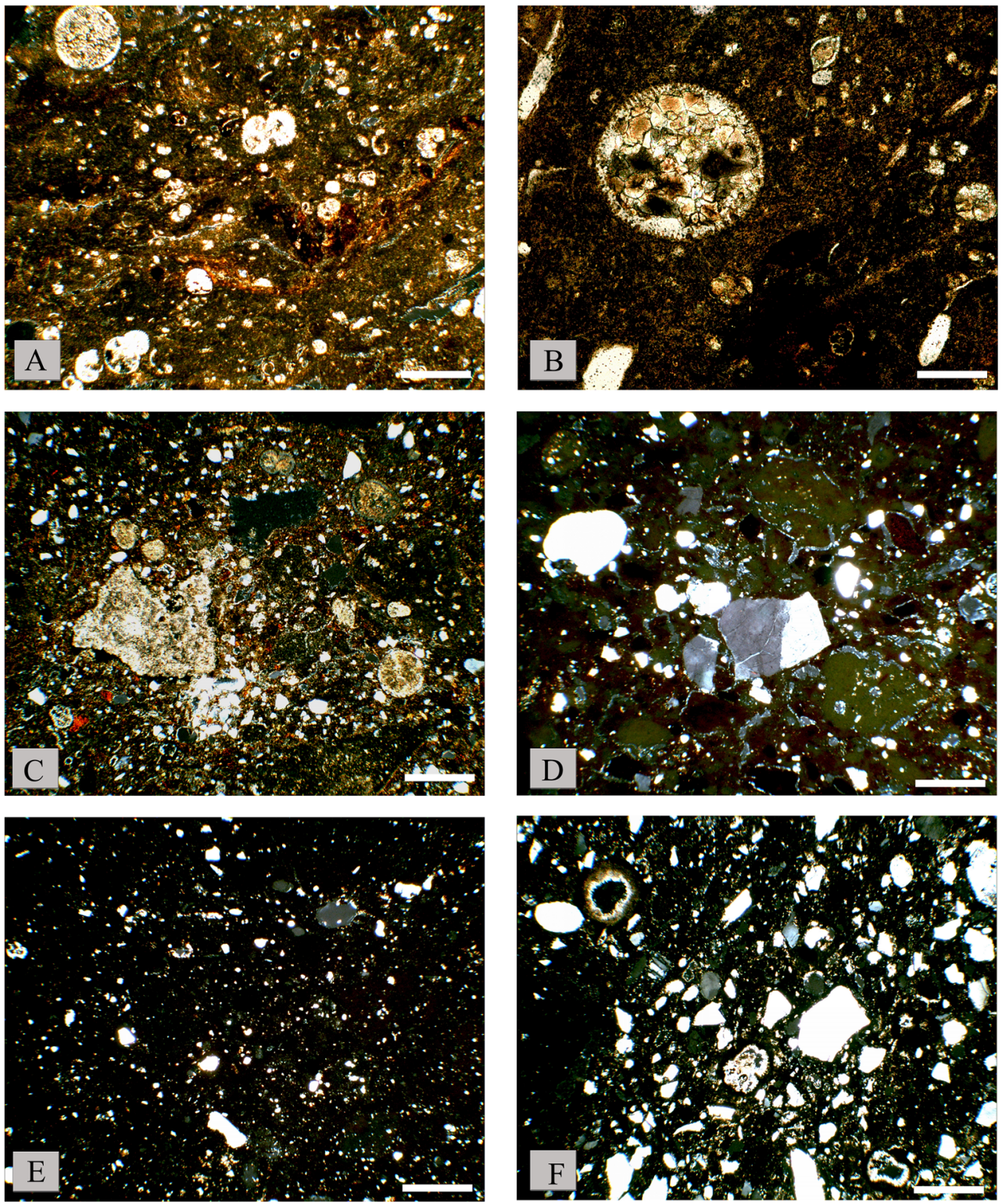

components only) was relatively higher, reaching the $15-20 \%$ area. Coarse silt $(0.04-0.06 \mathrm{~mm})$ and very fine sand $(0.06-$ $0.125 \mathrm{~mm}$ ) were more prevalent than other granulometric classes. Monocrystalline quartz was clearly more abundant than calcareous bioclasts (mainly transformed after the firing process) and the other siliciclastic constituents (polycrystalline quartz, K-feldspar, quartzarenite sub-rounded fragments, tiny mica flakes) and particles composed of iron oxides/ hydroxides (Fig. 9E).

The single SCP14 (relatively recent local brick) differed from all of the other studied structural clay products by its considerably higher siliceous aplastic grains abundance (up to $35-40 \%$ of area) and average size (medium and coarse sand grains prevailing). Monocrystalline and polycrystalline quartz were clearly the most represented components, followed by quartzarenite fragments, acid crystalline rock fragments (granitoid), K-feldspar (sporadic to rare) and common to sporadic more or less calcinated bioclasts (Fig. 9F).

The petrographic study of the analysed building materials showed the use and mixing exclusively of clays from the Marne di San Cipirello Formation (Mix-I). Differences in mixing were observed, increasing the proportions of the other locally available clays with lower calcareous components and a more abundant siliciclastic fraction (from Mix-II to Mix-III and Mix-IV). Besides the Marne di San Cipirello fabrics, one single petrographic fabric, SCP14, tempered with abundant sand exploited from the local Terravecchia Formation, which outcrops not far from the modern village of San Cipirello (Fig. 3), was identified.

The examination of the corresponding chemical data, shown in Table 5, fully confirms the division into subgroups obtained on the petrographic basis. There is a chemical 
concordance between the sub-fabrics Mix-I, Mix-II and MixIII in terms of the abundance of major elements. The Mix-I (7 samples) is distinguished by a higher $\mathrm{CaO}$ concentration, (from 25.05 to $38.81 \mathrm{wt} \%$ ) and relatively lower concentration of $\mathrm{SiO}_{2}$ (mean $\left.=40.71 \mathrm{wt} \%\right)$ and $\mathrm{K}_{2} \mathrm{O}($ mean $=1.96 \mathrm{wt} \%$ ). These values are compatible with the local clay deposits belonging to the Marne di San Cipirello Formation. Therefore, we suggest that these bricks and tiles were produced using $100 \%$ local raw materials (Fig. 10A). On the other hand, sub-fabric Mix-IV contains higher detrital quartz-feldspathic sand, so it has the lowest values of $\mathrm{CaO}$ (mean $=6.19 \mathrm{wt} \%$ ) and the highest concentrations of $\mathrm{SiO}_{2}($ mean $=59.06 \mathrm{wt} \%)$ and $\mathrm{K}_{2} \mathrm{O}$ (mean $=2.55 \mathrm{wt} \%$ ). The concentrations of the same oxides are relative in the other two subgroups (Mix-II and Mix-III), and they have intermediate values in Mix-I and Mix-IV. They, actually, progressively increasing from Mix-I to Mix-IV. The differences are also evident for the concentrations of $\mathrm{Al}_{2} \mathrm{O}_{3}, \mathrm{Fe}_{2} \mathrm{O}_{3}, \mathrm{MgO}$ and $\mathrm{TiO}_{2}$ (Fig. 10B).

Concerning trace elements, subgroup Mix-I stands out for its $\mathrm{Sr}$ (mean = $931 \mathrm{ppm}$ ), geochemically related to $\mathrm{Ca}$, compared to Mix-IV where the mean values of $\mathrm{Sr}$ are much lower (mean $=287 \mathrm{ppm})$. Almost all of the trace elements, excluding those whose abundances are close to the instrumental detection limit, present an increasing concentration trend going from Mix-I to Mix-IV. This is particularly evident for Sc, V, $\mathrm{Y}, \mathrm{Zr}, \mathrm{Ga}, \mathrm{Rb}, \mathrm{Nb}, \mathrm{Cs}, \mathrm{La}, \mathrm{Ce}$ and $\mathrm{Pb}$ (Fig. 10C-10D). It is not clear whether the mixtures of clayey raw materials found in the historical bricks/tiles following traditional methods can be related to supply sites in areas where the above-mentioned clay formations are "mixed in a natural way" (i.e. landslides, colluvial and/or alluvial deposits), or if they are to be considered "artificial mixing" with the aim of obtaining structural clay products with good technical performance. Only for the single sample SCP14 does the deliberate addition (tempering) of quartz-feldspar sand appear evident from a textural, mineralogical and chemical point of view.

\section{Archaeological pottery}

The thin-section observations under the polarizing microscope allowed the division of the analysed samples of Archaic mattpainted/incised indigenous pottery (60 individual samples collected from Monte Iato stratigraphic excavations) into 3 petrographic paste groups (PPG).

In PPG-I (11 samples: K 10769 B, K 16588, K 19201, K 19340, K 21979, K 23361, K 23761 B, K 24509 A, K 26020, K 26131 B, K 28424), aplastic inclusions are rather homogeneously distributed, mostly with $15 \%$ and $25 \%$ (area) packing. Regarding size, aplastic inclusions fall mainly in the coarse silt $(0.04-0.06 \mathrm{~mm})$ and very fine sand $(0.06-0.125 \mathrm{~mm})$ classes. Grain sizes ranging between 0.2 and $0.5 \mathrm{~mm}$ are subordinate, even if common. The predominant constituent is monocrystalline quartz, with angular to subangular granules. Common components were tiny mica crystals with lamellar habitus and feldspars (K-feldspar and plagioclase), both falling in the fraction of very fine sand and coarse silt. Subordinated components were chert and polycrystalline quartz. Partially decomposed microfossils, micritic clots or pore casts were unequivocally rare. The texture of the base mass was generally fairly homogeneous with sporadic lumps (Fig. 11A). Among the locally available raw materials, a composition characterized by low or very low calcareous inclusions pointed to the clayey materials of the Terravecchia and Tavernola Formations, both characterized by fine quartz, feldspar, mica aplastic inclusions and only small amounts of calcareous microfossils (Montana et al. 2011b). The modest outcrops of the Terravecchia Formation on the slopes of Monte Iato were distinguished by their lower siliceous sand content, often below 3\% (area). An analogous microfabric among the samples examined and classified in PPG-I was found in samples K 16588 and K 21979, which can also be considered fully compatible with the textural features of the local outcrops of the clay of the Terravecchia Formation. The remaining nine samples classified in PPG-I, on the other hand, are slightly dissimilar and show a greater frequency of siliciclastic inclusions (quartz, feldspars, mica). These textural features have not been found in the local outcrops of the Terravecchia Formation; however, they match what was already quantified for other outcrops of the same formation which are located near the site of Entella (DMS geographical coordinates: $37^{\circ} 46^{\prime} 26.5^{\prime \prime} \mathrm{N}$ $13^{\circ} 07^{\prime} 30.0^{\prime \prime} \mathrm{E}$; Montana et al. 2011a).

PPG-II consists of 40 samples: IK42, IK313, IK418, IK460, IK792, IK923, IK937, IK1262, K21972, K21998, K22010, K22031, K 22086, K 22089, K 22110, K 22112, K 22124, K 22125, K 22126, K 22127, K 22141 B, K 22142, K 22146, K 22147, K 22160, K 22163, K 22168, K 22169, K 22253, K 22255, K 22256, K 22259 B, K 22271 A, K 22288, K 24011, K 24418, K 24635, K 24640, K 27968 and K 26018. The samples grouped in PPG-II were characterized by a lumpy groundmass and a rather variable occurrence of aplastic inclusions, ranging from 10 to $25 \%$ (area). In terms of size, these grains are distributed among coarse silt $(0.04-0.06 \mathrm{~mm})$, very fine sand $(0.06-0.125 \mathrm{~mm})$ and fine sand $(0.125-0.25$ $\mathrm{mm})$. The inclusions reaching $0.5 \mathrm{~mm}$ are sporadic, while coarse $(0.5-1.0 \mathrm{~mm})$ and very coarse $(1-2 \mathrm{~mm})$ grains are even more rare. Concerning composition, the calcareous lithoclasts, bioclasts (usually planktonic and benthonic foraminifera) and micritic clots/pore cast formed after the firing process $\left(\mathrm{T}=800-900^{\circ} \mathrm{C}\right)$ were by far the major constituents. Subangular monocrystalline quartz granules were only sporadic or even rare (Fig. 11B). These compositional and textural characteristics were common to all 40 samples falling into PPG-II, absolutely matching what has already been attested for local clays ascribed to the Marne di San Cipirello Formation. 


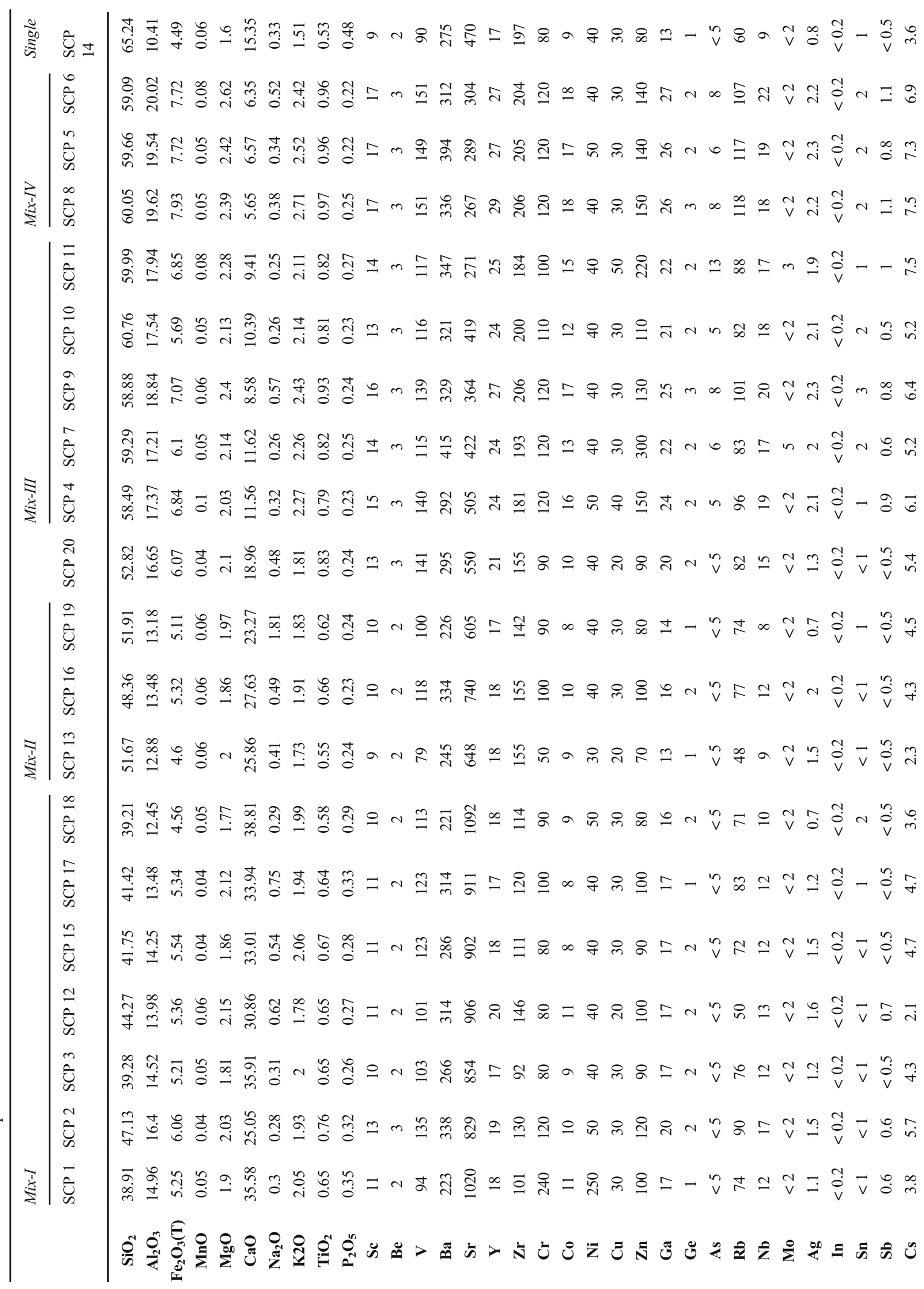




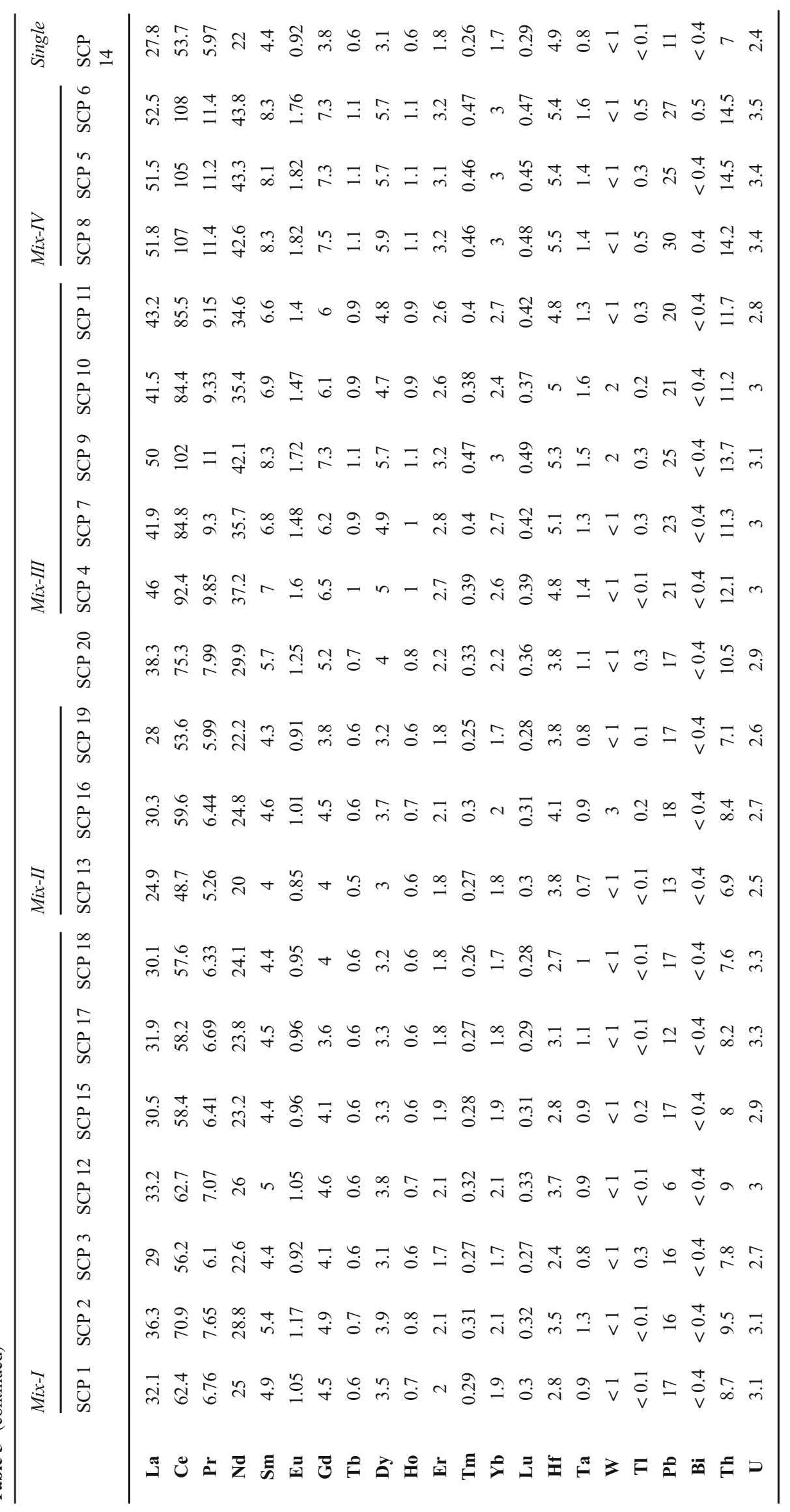


$\times$ Mix-I; O Mix-II; $\triangle$ Mix-III; is Mix-IV; $\square$ Terravecchia F.; $\square$ Marne S. Cipirello F.; $\diamond$ Tavernola F.
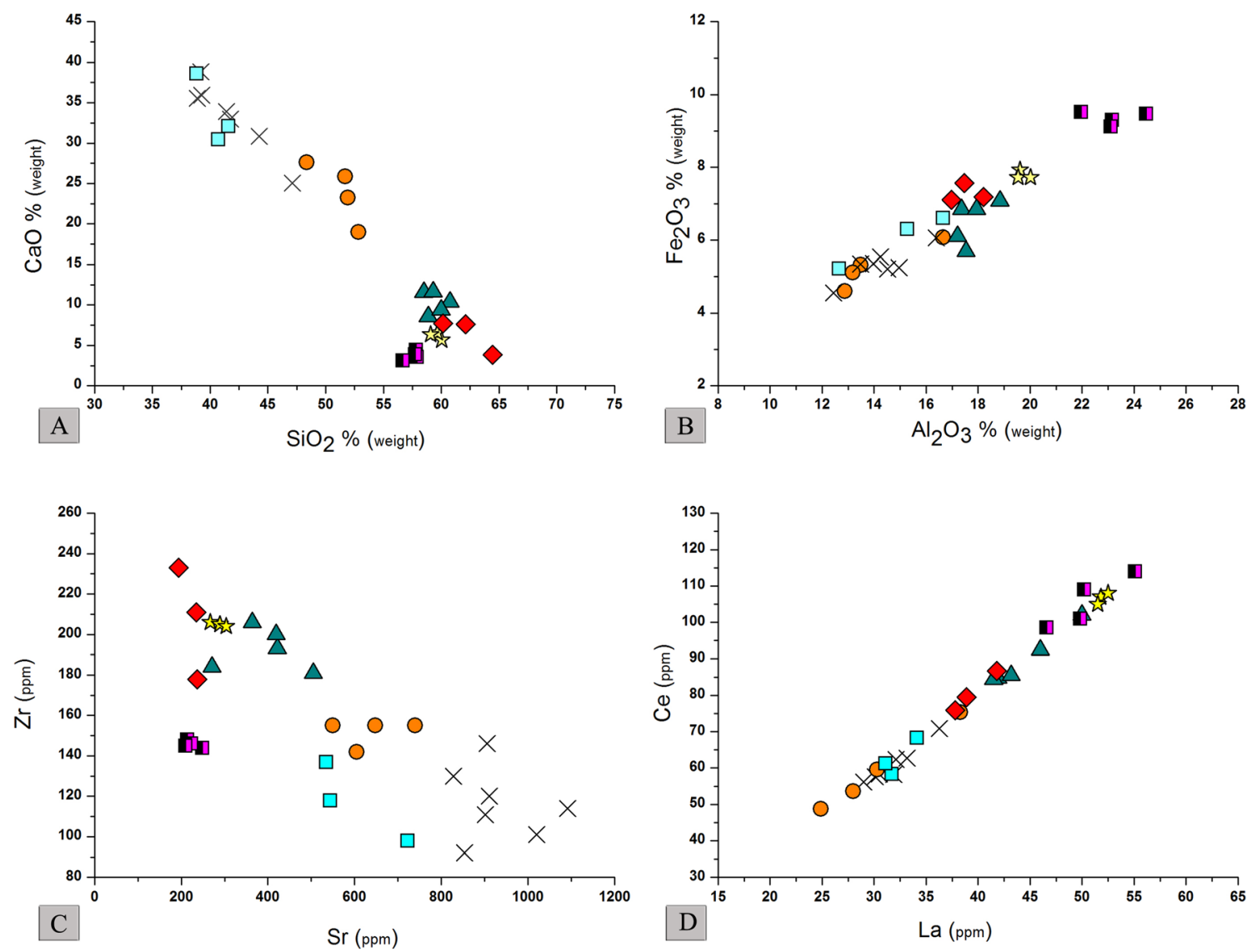

Fig. 10 Scatter plots $\mathrm{SiO}_{2}-\mathrm{CaO}(\mathbf{A}), \mathrm{Al}_{2} \mathrm{O}_{3}-\mathrm{Fe}_{2} \mathrm{O}_{3}(\mathbf{B}), \mathrm{Sr}-\mathrm{Zr}(\mathbf{C})$ and $\mathrm{La}-\mathrm{Ce}(\mathbf{D})$, showing the compositional matching between local raw clays and brick and tiles produced traditionally in the same territory based on major and trace elements

PPG-III consists of 9 samples: K $17218 \mathrm{C}, \mathrm{K} 17220 \mathrm{~B}, \mathrm{~K}$ 17249, K 17293, K 19366, K 22705 D, K 22912K, 22091 B and $\mathrm{K} 22113$. This paste was characterized by frequent clay lumps in the groundmass (heterogeneous texture) and inclusion packing ranging between 15 and $25 \%$ (area). The aplastic inclusions were quite homogeneously distributed, with sizes mainly falling in the classes of very fine sand $(0.06-0.125$ $\mathrm{mm})$ and fine sand $(0.125-0.25 \mathrm{~mm})$ and only sporadically in the coarse sand class $(0.5-1.0 \mathrm{~mm})$. Monocrystalline quartz was the most common monomineralic component, with grains from subangular to sub-rounded and size, mostly falling in the fine sand class. Calcareous microfossils (sometimes decomposed and transformed into micritic clots or irregular pores after the firing process) were relatively less common. Feldspars (K-feldspar and plagioclase), mica, chert and polycrystalline quartz are sporadic to rare (Fig. 11C). It should be
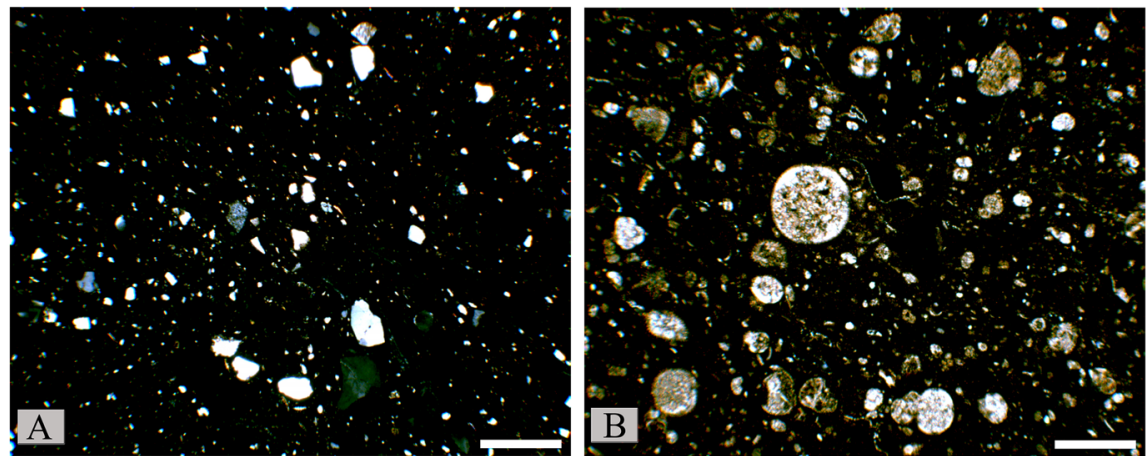

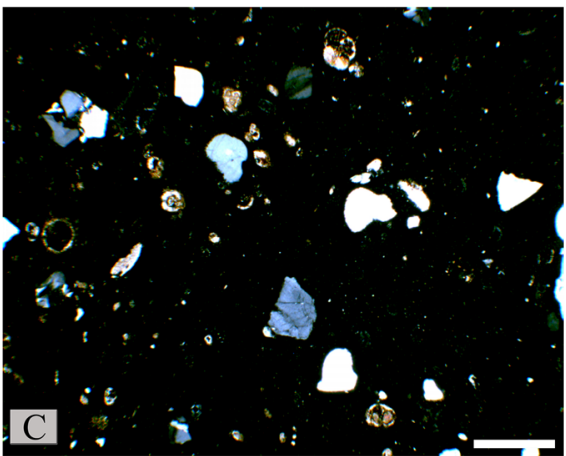

Iato. A PPG-I (sample K19201; crossed nicol, scale bar = 0.5 mm); B PPG-II (sample K21972; crossed nicol, scale bar = 0.5 mm); C PPG-III (sample K19366; crossed nicol, scale bar $=0.5 \mathrm{~mm}$ ) 
noted that the same textural and compositional characteristics have been verified in the local historical production of bricks and tiles for which the use of mixtures (natural or artificial) of local clays belonging to the Marne di San Cipirello Formation with the poorly calcareous and siliciclastic Terravecchia Formation or Tavernola Formation has been shown.

The chemical analysis of the Archaic indigenous pottery of Monte Iato confirms the results obtained by the petrographic study of the local traditional tiles and bricks. Up to three chemical paste groups (CPG) can be distinguished based on noticeable differences in chemical composition that match the above-described petrographic groups (Table 6). Predictably, these chemical groups showed marked differences in the concentrations of the most significant major and trace elements, which could be directly correlated to the mineralogical composition and textural features of the corresponding PPG (Figs. $12 \mathrm{~A}$ and $\mathrm{B})$.

CPG-I consists of the same samples as the PPG-I. Concerning the major elements, this paste is characterized by the highest average values of $\mathrm{SiO}_{2}($ mean $=63.88 \mathrm{wt} \%$; variation interval $=60.89-68.15 \mathrm{wt} \%), \mathrm{Al}_{2} \mathrm{O}_{3}($ mean $=17.58$ wt $\%$; variation interval $=15.32-19.01$ wt $\%) \mathrm{Fe}_{2} \mathrm{O}_{3}$ (mean = $7.19 \mathrm{wt} \%$; variation interval $=6.50-7.85 \mathrm{wt} \%)$ and $\mathrm{K}_{2} \mathrm{O}$ $($ mean $=2.59 \mathrm{wt} \%$; variation interval $=2.50-2.82 \mathrm{wt} \%)$, together with the lowest $\mathrm{CaO}$ concentrations (mean $=4.76 \mathrm{wt} \%$; variation interval $=3.46-7.07 \mathrm{wt} \%)$. The trace elements, with the exception of $\mathrm{Sr}$ (mean $=228 \mathrm{ppm}$ ), are relatively more concentrated than the other CPGs, in particular: $\mathrm{Ba}$ (mean = $529 \mathrm{ppm}), \mathrm{V}($ mean $=154 \mathrm{ppm}), \mathrm{Zr}($ mean $=228 \mathrm{ppm}), \mathrm{Rb}$ $($ mean $=112 \mathrm{ppm}), \mathrm{La}($ mean $=44 \mathrm{ppm})$ and $\mathrm{Ce}($ mean $=86$ $\mathrm{ppm}$ ). These compositional characteristics could be easily interpreted in light of what was observed through thinsection petrography, which emphasized the relatively higher frequency of aplastic inclusions composed of quartz, feldspars and mica, and the concurrent scarcity of calcareous microfossils. The relatively high contents of $\mathrm{Ba}$ and $\mathrm{Rb}$ (both with geochemical affinity towards K) can, therefore, be correlated to the feldspars and mica content (the latter finely dispersed in the groundmass). $\mathrm{Zr}, \mathrm{Y}$ and $\mathrm{Pb}$ are very often related to the presence of a significant siliciclastic detrital fraction. The abundance of light rare earth elements ( $\mathrm{La}$ and $\mathrm{Ce}$ ) might be related to textural aspects (the aplastic grains/groundmass ratio), given that their concentration generally tends to increase with decreasing aplastic grain packing.

CPG-II consists of the same samples as PPG-II. This group is distinguished from the others primarily by the $\mathrm{CaO}$ concentration $($ mean $=28.46 \mathrm{wt} \%$; variation interval $=25.13-39.42$ $\mathrm{wt} \%$ ), which is exceptionally high and by the consequent low concentration of $\mathrm{SiO}_{2}$ (mean $=44.66 \mathrm{wt} \%$; variation interval $=$ 38.18-46.99 wt\%), $\mathrm{Al}_{2} \mathrm{O}_{3}$ (mean $=15.19 \mathrm{wt} \%$; variation interval $=12.73-17.33 \mathrm{wt} \%)$ and $\mathrm{K}_{2} \mathrm{O}$ (mean $=2.26 \mathrm{wt} \%$; variation interval $=2.06-2.47 \mathrm{wt} \%$ ) due to the dilution effect (after Mommsen et al. 1988). Among the trace elements, $\mathrm{Sr}$ stands out for its high concentration $($ mean $=671 \mathrm{ppm}$; variation interval $=527-801 \mathrm{ppm})$, while the concentrations of $\mathrm{Ba}$ $($ mean $=373 \mathrm{ppm}), \mathrm{Zr}($ mean $=123 \mathrm{ppm})$ and $\mathrm{Rb}($ mean $=68$ ppm) are comparatively lower. The observed chemical characteristics can be easily interpreted in this case in light of the petrographic data, which have highlighted an extraordinary abundance of calcareous microfossils (mostly planktonic foraminifers) scattered in the groundmass. This also justifies the high concentration of $\mathrm{Sr}$, which is renowned to have a marked geochemical affinity with calcium.

CPG-III consists of the same samples as PPG III. The samples in this group have intermediate chemical characteristics with respect to the extreme ones, especially in terms of the $\mathrm{SiO}_{2} / \mathrm{CaO}$ ratio, found in the CPG-I and CPG-II: $\mathrm{SiO}_{2}$ mean concentration $=56.09 \mathrm{wt} \%$ (variation interval $=54.19-59.49$ $\mathrm{wt} \%) ; \mathrm{CaO}$ mean concentration $=14.63 \mathrm{wt} \%$ (variation interval $=12.45-16.39 \mathrm{wt} \%) ; \mathrm{Al}_{2} \mathrm{O}_{3}$ mean concentration $=$ $16.33 \mathrm{wt} \%$ (variation interval $=15.01-17.27 \mathrm{wt} \%$ ); and $\mathrm{K}_{2} \mathrm{O}$ mean concentration $=2.52 \mathrm{wt} \%$ (variation interval $=2.34$ $2.68 \mathrm{wt} \%$ ). The same considerations can be made for trace elements, for which the following average values were detected: $\mathrm{V}($ mean $=125 \mathrm{ppm}), \mathrm{Ba}($ mean $=494 \mathrm{ppm}), \mathrm{Sr}($ mean = $498 \mathrm{ppm}), \mathrm{Zr}($ mean $=173 \mathrm{ppm})$ and $\mathrm{Rb}($ mean $=88 \mathrm{ppm})$. These compositions are once again in excellent agreement with the petrographic results concerning the same ceramic samples, thus confirming the hypothesis of clay mixing.

\section{Assessment of local Archaic ceramic production}

The present ethnoarchaeometric approach to Archaic ceramic production in the indigenous settlement of Monte Iato and raw materials was based on the textural and compositional comparison between (a) archaeological finds, (b) experimental firing tests performed on local raw clays and (c) tiles and bricks certainly produced (following traditional procedures) in the same area in the more or less recent past. All of the petrographic and chemical data obtained from the 90 samples (60 archaic matt-painted and incised indigenous pottery, 10 local clay samples and 20 tiles and bricks) sampled at the territory of San Giuseppe Iato and San Cipirello points to the following:

1) The raw material used for paste-I (Mix-IV, PPG-I/CPG-I) is characterized by a very low content of calcareous microfossils and much more abundant fine aplastic inclusions mainly composed of quartz (prevalent), feldspars and mica. This is compatible with the clays of the Terravecchia Formation that outcrop in the surroundings of Monte Iato to the east of the inhabited area of San Cipirello.

2) Paste-II (Mix-I, Mix-II, PPG-II/CPG-II) is characterized by a predominant or abundant calcareous component, characteristic and mainly represented by planktonic 


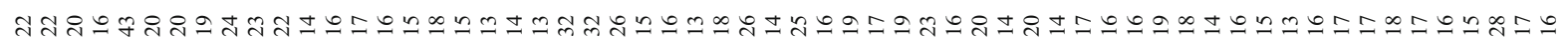

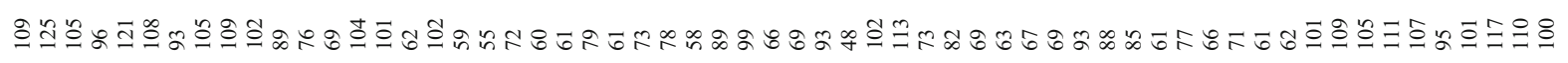

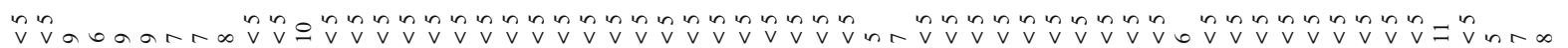

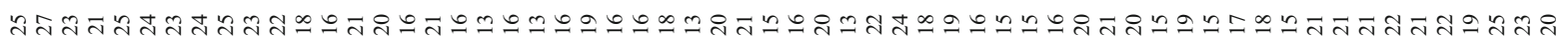

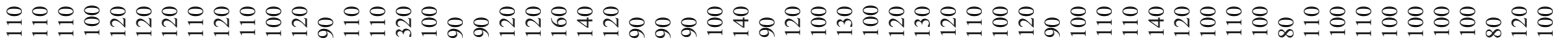

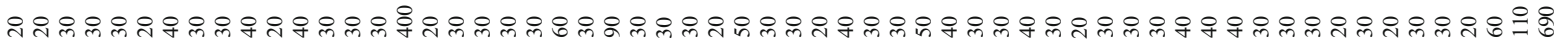

$\bar{z}$

¿

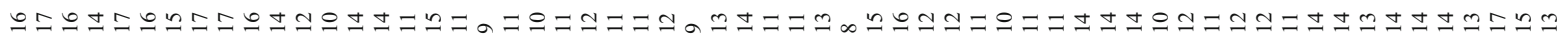

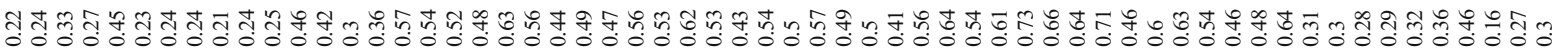

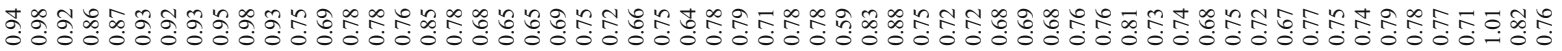

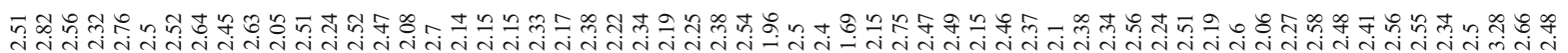

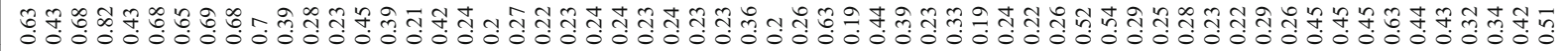

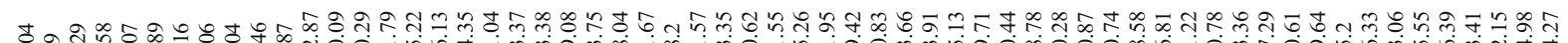

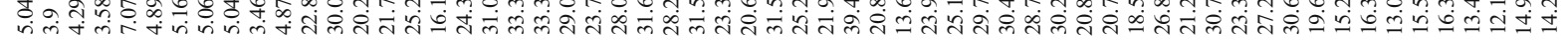

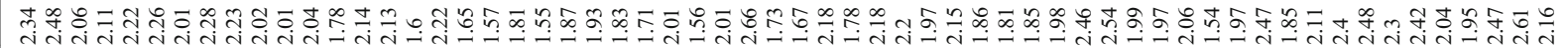

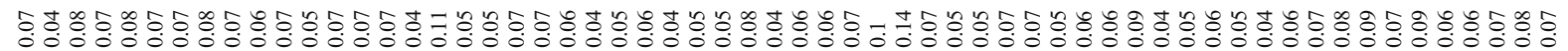

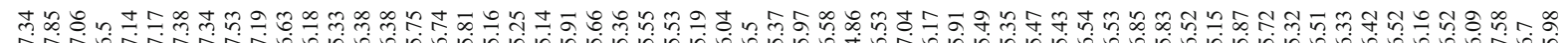

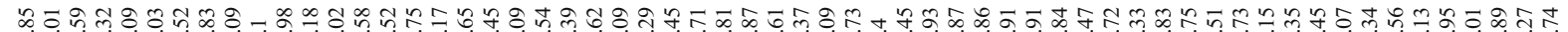

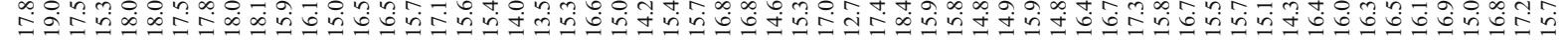
ชำ

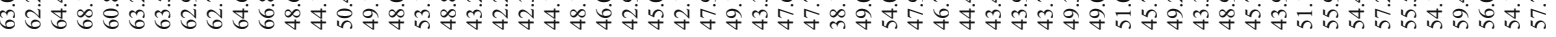

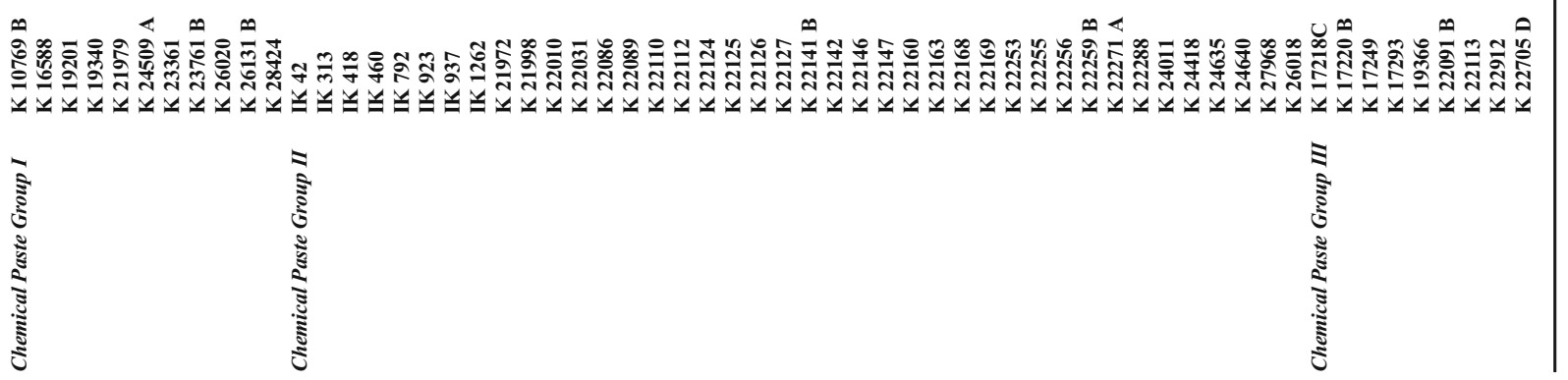




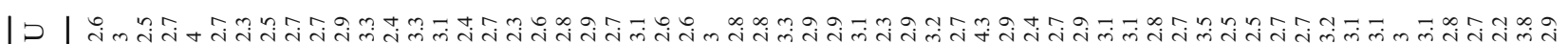

F

$\bar{n}$

운

$F$

3

๘

生

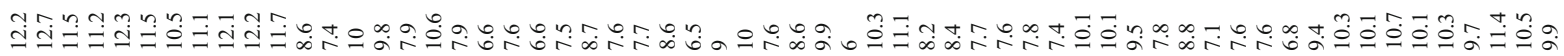

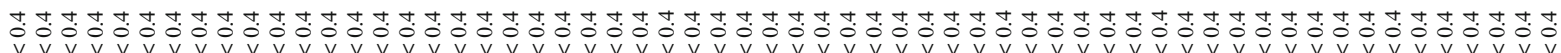
ス

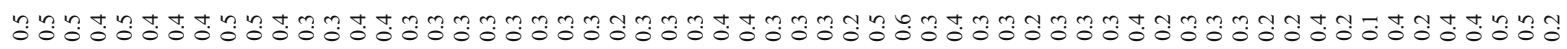
$--\vec{v} a r--\vec{v}-b \vec{v} \vec{v} \vec{v} \vec{v} \vec{v} \vec{v} \vec{v} \vec{v} \vec{v}-\vec{v} a-\vec{v} \vec{v} \vec{v} \vec{v} a-\vec{v} \vec{v} \vec{v} \vec{v} \vec{v} r m \vec{v} \vec{v}-\vec{v} \vec{v} n \vec{v} \vec{v}-a-\vec{v} \vec{v}--\vec{v} \vec{v}-\vec{v}-a \vec{v} r \vec{v}$

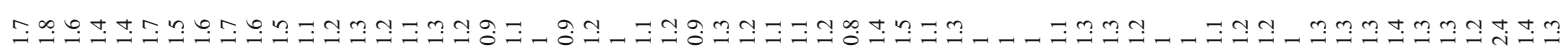

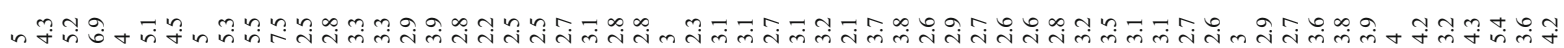

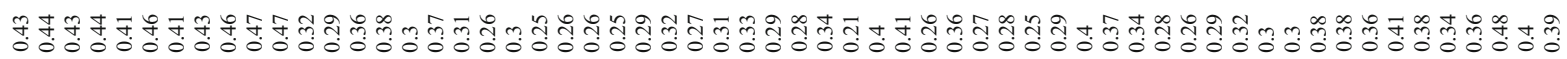

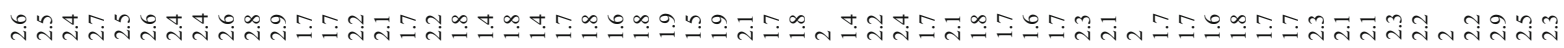

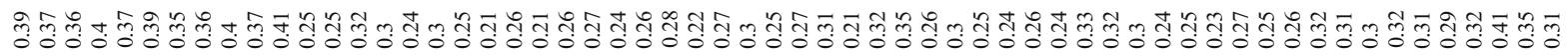

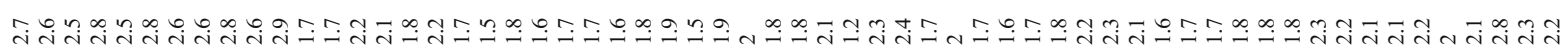
- - ò-

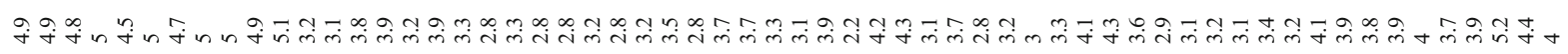

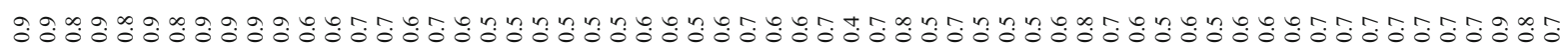

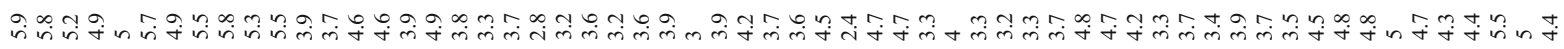

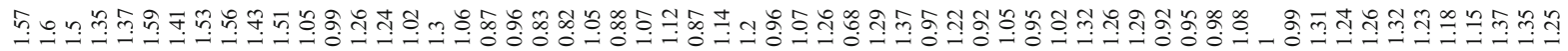

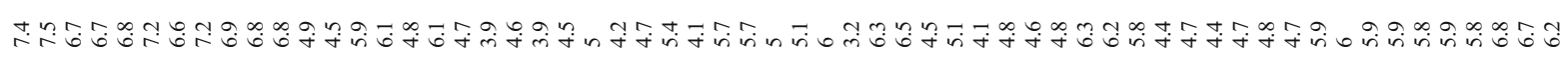

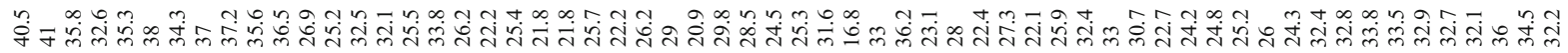

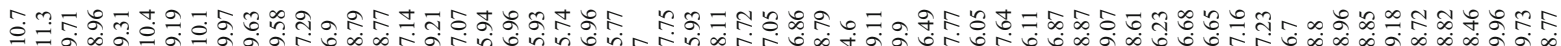

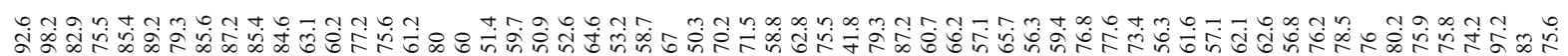

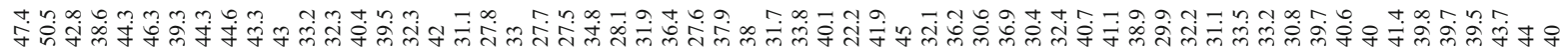

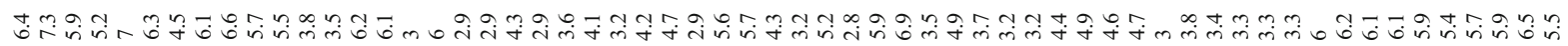

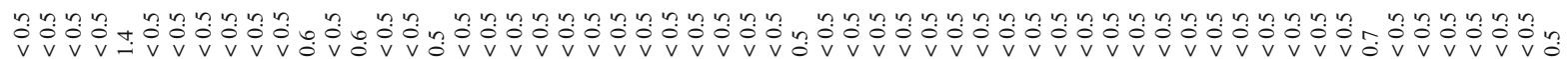

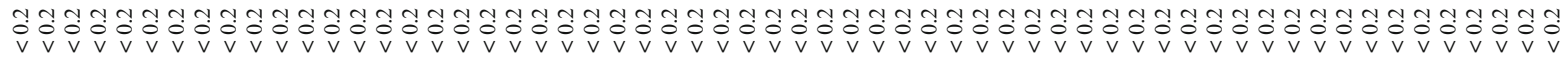

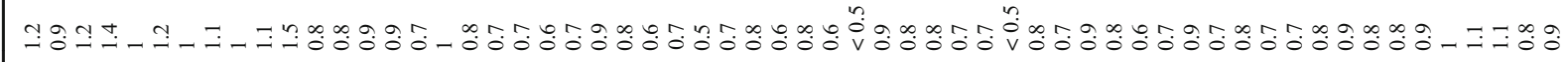

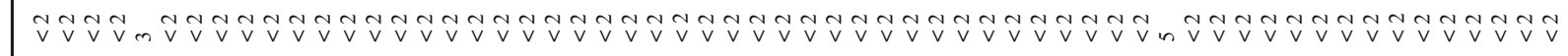

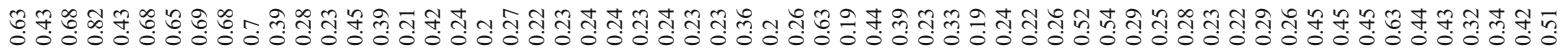

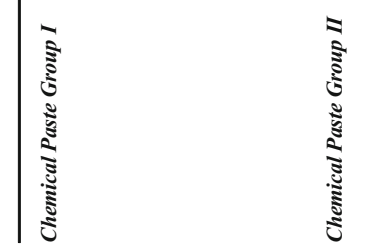


foraminifers (Orbulina suturalis, Orbulina universa, Globorotalia peripheroronda, Globigerinoides trilobus), sometimes strongly altered by the firing process. This composition matches the experimental briquettes made with one of the clays sampled in the Marne di San Cipirello deposits that outcrop widely in the vicinity of Monte Iato fired at $900{ }^{\circ} \mathrm{C}$ (see Figs.7C-D, 9A-B and 11B).

3) Paste-III (MIX-III, PPG-III/CPG-III), due to its peculiar textural and compositional characteristics based on the presence of both quartz-feldspathic-micaceous and calcareous inclusions (deriving from partial or complete thermal decomposition of microfossils), might as well be the result of a mixing (unpremeditated or intentional) of the clayey materials coming from the Marne di San Cipirello (extremely fossiliferous) with clays from the Terravecchia Formation (with prevailing inclusions of a quartz-feldspathic-micaceous nature).

All of the above-described ceramic pastes (fabrics) are compatible with the locally available clay raw materials. The combined statistical interpretation of the quantitative petrographic data (mineralogical composition, textural features and aplastic inclusions) combined with the chemical data enable the further and better discrimination of the groups. In concrete, the use of MCA proposed by Cau Ontiveros et al. (2004) yielded reliable groups. Nominal variables (i.e. aplastic sorting, presence/absence of specific minerals and/or lithic fragments, optical activity of the groundmass and pore shape) and ordinal variables (i.e. grain size, inclusion packing by area $\%$, the relative abundance of specific minerals and/or lithic fragments and pore size frequency) can be converted into binary values to generate a data matrix that, conjointly with numerical data, can be interpreted using multivariate statistical methods. MCA is a descriptive and exploratory statistical treatment designed to analyse large data sets that include different types of information (e.g. Baxter et al. 2008; Baxter 2009; Montana et al. 2009 and 2012; Angourakis et al. 2018; Montana et al. 2018). The variables and conversion values of the different qualifiers are shown in full in Supplementary Material Table S1, which has 21 columns and 77 rows. Each column represents a variable with a numerical value corresponding to one specific or a combination of two or more categories. The MCA graphs (of the 21 variables

- CPG-II; $\square$ CPG-I ; $\triangle$ CPG-III
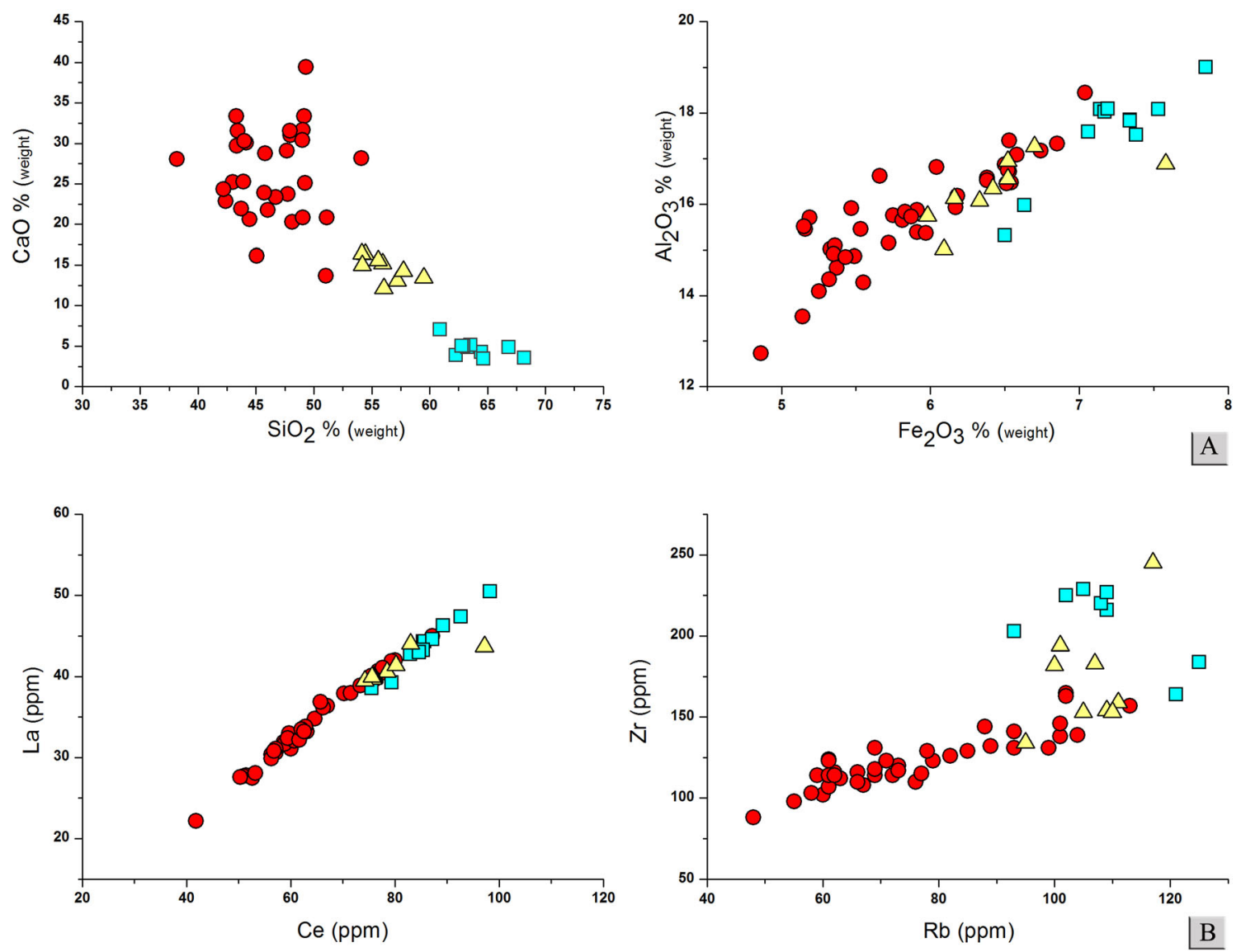

Fig. 12 Scatter plots relating to some selected major and trace elements ratios leading to the distinction of three chemical paste groups: $\mathbf{A} \mathrm{SiO}_{2}-\mathrm{CaO} ; \mathbf{B}$ $\mathrm{Fe}_{2} \mathrm{O}_{3}-\mathrm{Al}_{2} \mathrm{O}_{3}$; C Ce-La; D Rb-Zr 
Multiple Correspondence Analysis

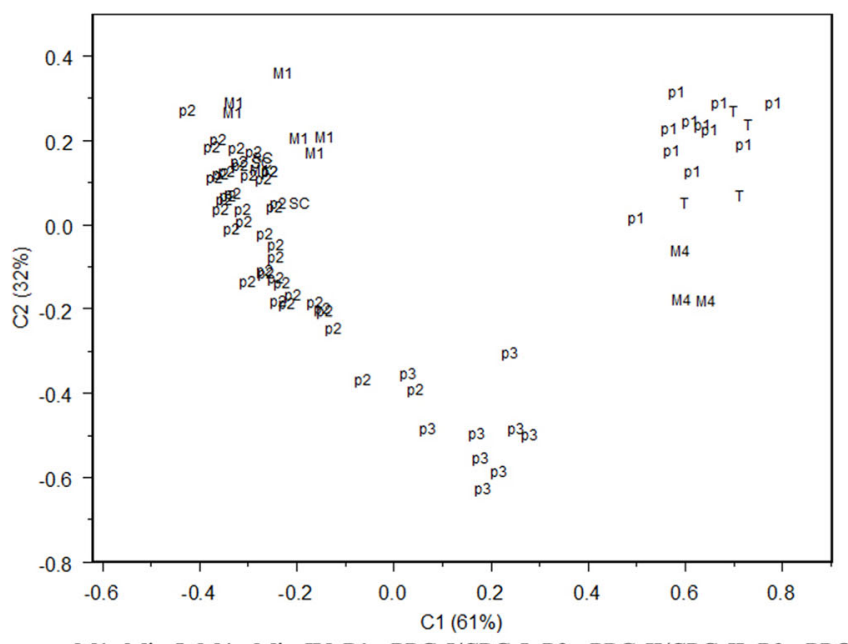

M1=Mix-I; M4= Mix-IV; P1= PPG-I/CPG-I; P2= PPG-II/CPG-II; P3= PPG-II

Fig. 13 MCA comparing archaeological artefacts (PPG/CPG-I, PPG/ CPG-II and PPG/CPG-III), traditional brick and tiles (Mix-I and MixIV) and local clays (Marne di San Cipirello and Terravecchia

in Supplementary Material Table S2) are presented in Fig. 13. On the left is the scatterplot of the two first components and on the right are the loadings (that correspond to the variables). The graphs contain over $93 \%$ of the variability (total variance $=0.93$ ). As can be seen, first of all, pastes I, II and III are separated in a satisfactory way by both components, forming groups with acceptable homogeneity. The groups I, II and III are well separated by both components forming quite homogenous groups. There is a convergence of paste I (Mix-IV, PPG-I/CPG-I) with the clays from the Terravecchia Formation, while paste II (Mix-I, Mix-II, PPG-III/CPG-III)

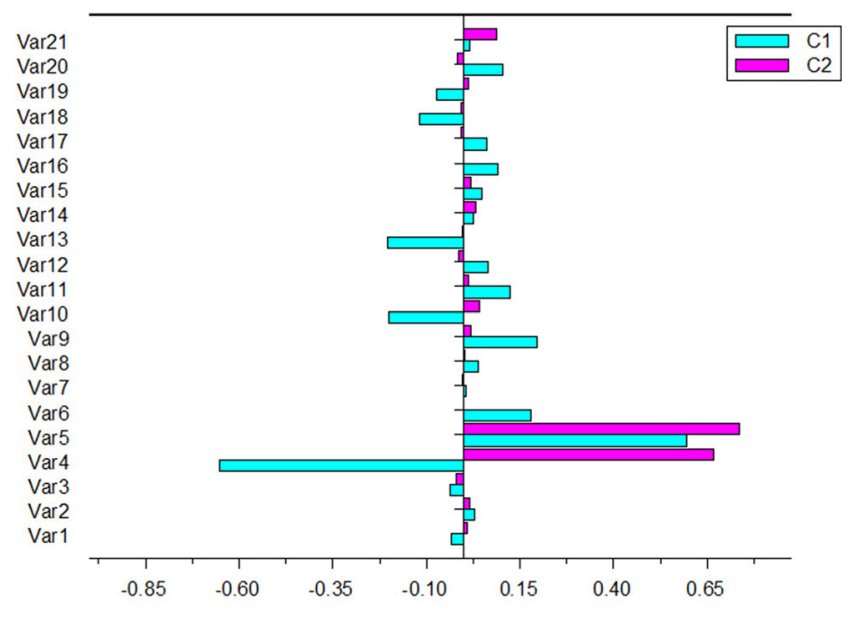

IICPG-III; T=Terravecchia Formation; SC= Marne S. Cipirello Formation

Formations). Scores on the first two components (up to $93 \%$ of total variance) are showed on the left while loadings on $\mathrm{C} 1$ and $\mathrm{C} 2$ on the right

is related to the clays of the Marne di San Cipirello Formation. Finally, the individuals grouped in paste III (MIXIII, PPG-III/CPG-III) are slightly separate from both the above groups, although somewhat related to them, corroborating the hypothesis that they must be mixtures (natural or artificial) of these local clays.

Regarding the ceramic paste I of Monte Iato, we must consider the possibility of imports from the site of Entella in the Sicani mountains, about $80 \mathrm{~km}$ away from Monte Iato. The only Archaic kiln site in Sicily is documented in Entella. It produced indigenous matt-painted pottery using the clays
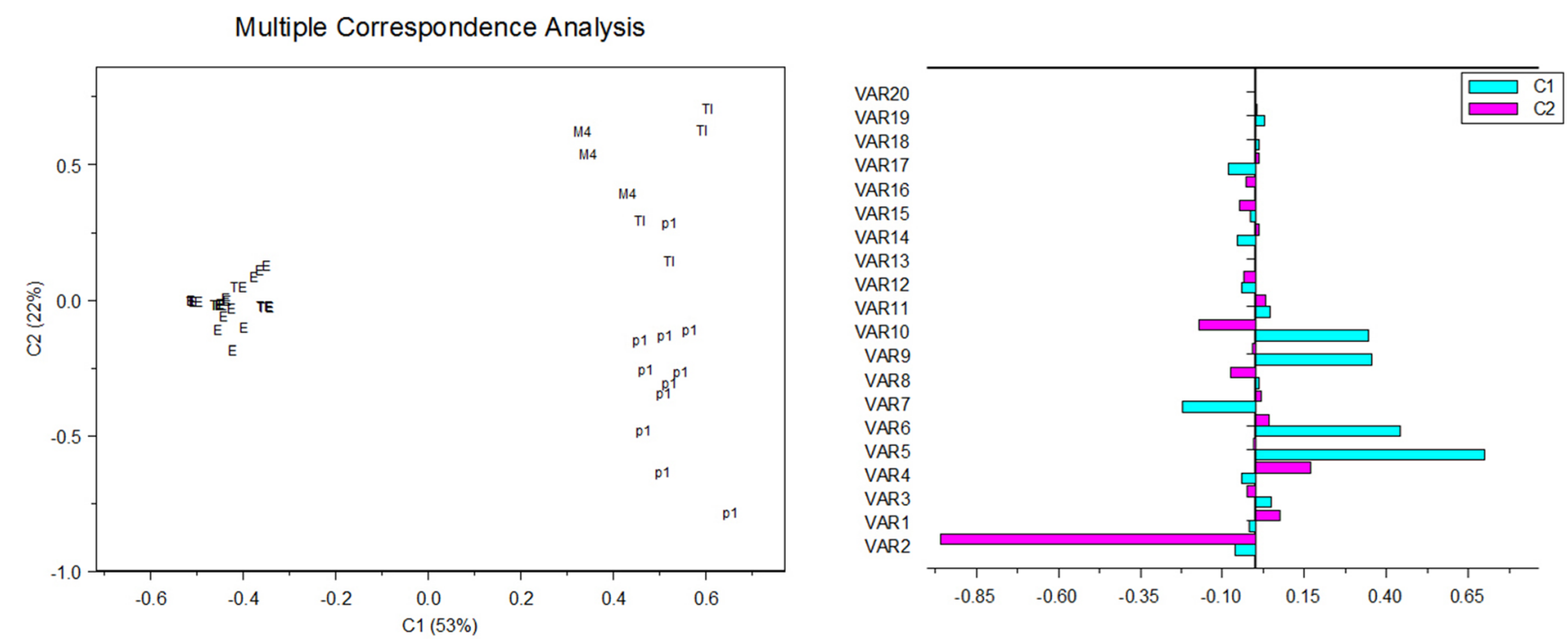

E=Entella; M4=Mix-IV; TI=Terravecchia Formation, Iato; TE=Terravecchia Formation, Entella; P1=PPG-I/CPG-I

Fig. 14 MCA comparing archaeological artefacts from Monte Iato (PPG/ CPG-I), local traditional brick and tiles (Mix-IV), local clay (Terravecchia Formation), Archaic indigenous matt-painted pottery from Entella and corresponding raw clay (Terravecchia Formation sampled at the slope of Rocca di Entella, after Montana et al. 2017). Scores on the first two components (up to $75 \%$ of total variance) are showed on the left while loadings on $\mathrm{C} 1$ and $\mathrm{C} 2$ on the right 
from the local outcrops of the Terravecchia Formation (Montana et al. 2017).

The application of MCA for the basic comparison of ceramic paste I (Monte Iato), the clays of the Terravecchia Formation, the traditional bricks (Mix-4) of San Giuseppe Iato, the matt-painted indigenous pottery produced at Entella and the clays of the local outcrops of the Terravecchia Formation made it possible to establish a clear distinction between the two different ceramic manufactures (Fig. 14 and Supplementary Material Table S3). However, one sample from paste I is grouped with the clays (Terravecchia Formation sampled at San Giuseppe Iato) and the locally produced bricks, while all of the others (10 samples) are separated. Following the corresponding factor loading graph (Fig. 14 right), it seems that this separation (positive loadings on $\mathrm{C} 1$ and negative on $\mathrm{C} 2$ ) is essentially based on textural aspects.

Table 7 Reference chemical composition for the Archaic mattpainted indigenous pottery produced on Monte Iato

\begin{tabular}{|c|c|c|c|}
\hline \multicolumn{2}{|c|}{ Samples no. $=50$} & \multirow{2}{*}{$\begin{array}{l}\text { Mean } \\
45.53\end{array}$} & \multirow[b]{2}{*}{3.87} \\
\hline $\mathrm{SiO}_{2}$ & $\mathrm{Wt} \%$ & & \\
\hline $\mathrm{Al}_{2} \mathrm{O}_{3}$ & $\mathrm{Wt} \%$ & 15.50 & 1.29 \\
\hline $\mathrm{Fe}_{2} \mathrm{O}_{3}(\mathrm{~T})$ & $\mathrm{Wt} \%$ & 5.81 & 0.58 \\
\hline $\mathrm{MnO}$ & $\mathrm{Wt} \%$ & 0.06 & 0.02 \\
\hline $\mathrm{MgO}$ & $\mathrm{Wt} \%$ & 1.96 & 0.26 \\
\hline $\mathrm{CaO}$ & $\mathrm{Wt} \%$ & 27.40 & 5.96 \\
\hline $\mathrm{Na}_{2} \mathrm{O}$ & $\mathrm{Wt} \%$ & 0.31 & 0.13 \\
\hline $\mathrm{K}_{2} \mathrm{O}$ & $\mathrm{Wt} \%$ & 2.24 & 0.26 \\
\hline $\mathrm{TiO}_{2}$ & $\mathrm{Wt} \%$ & 0.72 & 0.07 \\
\hline $\mathrm{P}_{2} \mathrm{O}_{5}$ & $\mathrm{Wt} \%$ & 0.48 & 0.13 \\
\hline $\mathrm{Sc}$ & ppm & 12 & 2 \\
\hline $\mathrm{V}$ & ppm & 114 & 16 \\
\hline $\mathrm{Ba}$ & ppm & 497 & 165 \\
\hline $\mathrm{Sr}$ & ppm & 683 & 138 \\
\hline $\mathrm{Y}$ & ppm & 19 & 2 \\
\hline $\mathrm{Zr}$ & ppm & 122 & 17 \\
\hline $\mathrm{Cr}$ & ppm & 84 & 27 \\
\hline $\mathrm{Co}$ & ppm & 10 & 2 \\
\hline $\mathrm{Ni}$ & $\mathrm{ppm}$ & 45 & 30 \\
\hline $\mathrm{Cu}$ & ppm & 40 & 53 \\
\hline $\mathrm{Zn}$ & ppm & 111 & 35 \\
\hline $\mathrm{Ga}$ & ppm & 17 & 3 \\
\hline As & ppm & 7 & 2 \\
\hline $\mathrm{Rb}$ & ppm & 75 & 15 \\
\hline $\mathrm{Nb}$ & ppm & 17 & 5 \\
\hline $\mathrm{Sn}$ & ppm & 2 & 1 \\
\hline Cs & ppm & 4 & 1 \\
\hline $\mathrm{La}$ & ppm & 34 & 5 \\
\hline $\mathrm{Ce}$ & ppm & 63 & 9 \\
\hline $\operatorname{Pr}$ & ppm & 7 & 1 \\
\hline $\mathrm{Nd}$ & ppm & 26 & 4 \\
\hline
\end{tabular}

The abundance of the fine siliciclastic sandy fraction in the ceramic products is higher than in the analysed clays (four samples).

This result, however, may not preclude the possibility of local production at Monte Iato for paste I. The results for this last paste might indicate changes in the digging areas from the same sources today compared those exploited in antiquity. That might be an effect of changes in the natural landscape in the last century. It is also evident that the production of matt-painted indigenous pottery during the Archaic period (seventh-fifth centuries BCE) is represented from the compositional point of view by paste-II (PPG-II/CPG-II), which represents about $70 \%$ of the archaeological finds studied (40 out of 60 samples) and is easily recognizable and distinguishable based on the specific petrographic and chemical characteristics discussed above, resulting from the exclusive use of clays from the local outcrops of the Marne di San Cipirello Formation. The use of the Marne di San Cipirello clays has been also attested in a dozen artefacts ascribable to the same ceramic class (Late Archaic contexts) at Erice, in northwestern Sicily, even if these to some extent show different petrographic and chemical characteristics (Montana et al. 2019). Table 7 shows the average composition values for paste II (PPG-II/CPG-II), including raw clays and bricks (Mix-I pastes), for a total of 50 samples. It could constitute a reliable reference group for future archaeological and archaeometric research topics inherent to provenance determination and regional distribution of the Archaic matt-painted and incised indigenous pottery in Sicily.

\section{Conclusions}

The ethnoarchaeometric approach at Monte Iato allowed the identification of valid minero-petrographic and characteristic chemical markers of the Archaic indigenous pottery produced there, despite the lack of archaeologically attested pottery kilns from that period. Local clay sources (raw material) have been documented, and some significant steps of the chaine opératoire adopted in antiquity have been identified (i.e. clay mixing and tempering practices). These results also enable the confirmation of the technical choices adopted by several contemporary traditional potters in western Sicily in terms of clay sourcing, pre-treatment and firing criteria as a long-lived tradition (Montana et al. 2015; Tsantini et al. 2017; Montana et al. 2018; Montana 2020).

The minero-petrographic and chemical analyses enable the division of the analysed material into paste groups (PGs) and subgroups. We can confirm the use of local raw clays from the Marne of San Cipirello Formation and, subordinately, from the Terravecchia Formation for the analysed pottery. This new archaeometric data are a significant contribution to our knowledge and open new perspectives for future 
archaeological research on the production of Archaic local ceramics with incised and painted decoration. Nevertheless, we still need to understand better the great variety of specialized workshops that produced specific ceramic types and classes and their wide diffusion.

There is archaeological evidence of the wide use of both painted and incised pottery in different sites, if we take into consideration other indigenous settlements in the Belice river basin (Monte Maranfusa, Monte Castellazzo di Poggioreale, Entella, Castello della Pietra, Montagnoli, Monte Adranone) beside the ones at Monte Iato. On the other hand, some peculiarities in forms and decorative motifs can be also observed between the various settlements. The lack of excavated Archaic kilns is not a valid argument to propose the existence of one sole centralized production or one sole distribution area, and that area cannot be considered exclusively Entella, where there is an Archaic kiln that produced pottery with painted geometric decoration. That workshop is located outside the urban perimeter, in an area that was later used as a necropolis. Moreover, there is a well-known preference for extra or peri-urban areas for allocating craft workshops, which are best suited in providing adequate space for clay processing, pottery drying and firing. The excavations conducted at these sites were often concentrated within the inhabited areas and only rarely involved areas located outside them, with the consequent difficulty in identifying artisanal areas intended for production in modern excavations.

On the other hand, increasingly refined archaeometric analyses and more in-depth geological investigations of the ceramic raw clays existing in the territory of western and central Sicily can add very important elements for a comprehensive localization of other new production centres. In the specific case of Monte Iato, the relevance of PG-II (raw clay source: Marne di San Cipirello), which includes all of the examined samples attributable to the class of incised indigenous ceramics, leads us to believe that the production of this ceramic class (until the middle/end of the sixth century BCE) took place exclusively at this site. If we consider that 25 fragments of painted pottery belong to PG-II, it follows that at least some of the vessels with painted geometric decoration were also locally produced.

We must also point out that the pots with painted decoration, petrographically and chemically assigned to the PG-I (raw clay source: Terravecchia Formation, compatible with clays located in the vicinity of the Monte Iato site but equally attested near Entella), are mostly limited to large shapes, being both open (craters) and closed (amphorae). We should consider whether the choice of raw clay with very fine aplastic inclusions and relatively lower $\mathrm{CaO}$ abundance was due to its suitability for these vessels and their functionality. Moreover, there is still no clear evidence of the existence of one single specialized production area (e.g. Entella). We should also consider the possibility that those vessel types might have been produced in other settlements located in the broader territory, because the upper Miocene clay of the Terravecchia Formation also outcrops in several areas across the Belice river basin and central Sicily (Montana et al. 2011c). On the other hand, the samples classified in PG-III (clay from the Marne di San Cipirello mixed with clays from the Terravecchia Formation) seem to include other forms, such as the typical jugs with painted geometric decoration, which were widely attested at Monte Adranone and Monte Maranfusa (Trombi 2015). Therefore, we must accept the probability that those types have been made at Monte Iato using local clays and widely distributed across a broader territory.

To conclude, we can state that Monte Iato is an area of Archaic ceramic production under study. All of the results (microscopic fabric and the average composition of local ceramic pastes) open new perspectives on the complex issue of the local/regional production and distribution of incised or painted indigenous ceramics in Archaic Sicily. This study emphasizes how ethnoarchaeometry is useful for understanding the criteria for sourcing clayey raw material, intra-production compositional variability and the functionality of the finished products. This model for a multidisciplinary approach can be replicated and adapted to other case studies in the same territory, with the advantageous result that the compositional data obtained can be used diachronically.

Supplementary Information The online version contains supplementary material available at https://doi.org/10.1007/s12520-021-01380-7.

Acknowledgments For enabling us to conduct the ethnoarchaeometric survey, we are extremely grateful to the director of the Ietas Excavations of the University of Zurich, Christoph Reusser, as well as the former and current directors of the archaeological park of Monte Iato, Ferdinando Maurici, Enrico Caruso, Lucina Gandolfo and Francesca Spatafora. We also want to express our gratitude to Frank Tomio for the professional preparation of the archaeological illustrations. The authors would like to thank the anonymous reviewers and the editor for their insightful suggestions and careful reading of the manuscript.

Funding Open access funding provided by Università degli Studi di Palermo within the CRUI-CARE Agreement. Research on the local pottery production on Archaic Monte Iato as well as the ethnoarchaeometric approach for outlining them was funded by the Jubiläumsfond der Österreichischen Nationalbank (project nr. 14960).

Open Access This article is licensed under a Creative Commons Attribution 4.0 International License, which permits use, sharing, adaptation, distribution and reproduction in any medium or format, as long as you give appropriate credit to the original author(s) and the source, provide a link to the Creative Commons licence, and indicate if changes were made. The images or other third party material in this article are included in the article's Creative Commons licence, unless indicated otherwise in a credit line to the material. If material is not included in the article's Creative Commons licence and your intended use is not permitted by statutory regulation or exceeds the permitted use, you will need to obtain permission directly from the copyright holder. To view a copy of this licence, visit http://creativecommons.org/licenses/by/4.0/. 


\section{References}

Angourakis A, Ferreras VM, Torrano A, Gurt Esparraguera GM (2018) Presenting multivariate statistical protocols in $\mathrm{R}$ using Roman wine amphorae productions in Catalonia, Spain. J Archaeol Sci 93:150-165

Baxter MJ (2009) Archaeological data analysis and fuzzy clustering. Archaeometry 50(6):1035-1054

Baxter MJ, Beardah CC, Papageorgiou I, Cau MA, Day PM, Kilikoglou V (2008) On statistical approaches to the study of ceramic artefacts using geochemical and petrographic data. Archaeometry 50(1):142-157

Catalano R, Avellone G, Basilone L, Sulli A (2010) Note illustrative del F. 607 "Corleone" della Carta Geologica d'Italia alla scala 1:50.000, 186, 392, F. Lentini, S. Carbone (eds), pp. 58 ff., ISPRA (Italy)

Cau Ontiveros MA, Day PM,Montana G (2002) Secondary calcite in archeological ceramics: evalutation of alteration and contamination processes by thin section study. In "Modern Trends in Scientific Studies on Ancient Ceramics", V. Kilikoglou, A. Hein, Y. Maniatis (eds). British Archaeological Reports (BAR), International Series 1011, p. 9-18

Cau Ontiveros MA, Day PM, Baxter MJ, Papageorgiou I, Iliopoulos I, Montana G (2004) Exploring automatic grouping procedures in ceramic petrology. J Archaeol Sci 31:1325-1338

Gasparo Morticelli M, Avellone G, Sulli A, Agate M, Basilone L, Catalano R, Pierini S (2017) Mountain building in NW Sicily from the superimposition of subsequent thrusting and folding events during Neogene: structural setting and tectonic evolution of the Kumeta and Pizzuta ridges. Journal of Maps 13:276-290

Isler HP (2000) Monte Iato. Guida archeologica, Sellerio editore, Palermo

Kistler E (2017) Lokal divergierende Antworten auf die Krater-isolierung West- und Mittelsiziliens (6./5. Jh. v. Chr.) - Perspektiven des Binnenlandes. In Cappuccini, L., Leypold, C., Mohr, M. (eds.) Fragmenta Mediterranea. Contatti, tradizioni e innovazioni in Grecia, Magna Grecia, Etruria e Roma, Studi di onore di Christoph Reusser, All'Insegna del Giglio, Firenze, pp 111-131

Kistler E, Mohr M (2015) Monte Iato. Two Late Archaic Feasting Places between the Local and the Global In Kistler, E., Öhlinger, B., Mohr, M.,Hoernes M. (eds.), Sanctuaries and the Power of Consumption. Networking and the Formation of Elites in the Archaic Western Mediterranean World. Proceedings of the International Conference in Innsbruck, 20th-23rd March 2012. Philippika, 92, Harrassowitz Verlag (Wiesbaden), pp 385-415

Kistler E, Mohr M (2016) The Archaic Monte Iato: Between Coloniality and Locality. In: H. Baitinger (Ed.), Materielle Kultur und Identität im Spannungsfeld zwischen mediterraner Welt und Mitteleuropa (Mainz, 2016), pp 81-98

Kistler E, Öhlinger B, Dauth T, Irovec R, Wimmer B (2017) Archaika as a Resource. The production of locality and colonial empowerment on Monte Iato (Western Sicily) around 500 BC. In: Scholz AK, Bartelheim M, Hardenberg R, Staecker J (eds) ResourceCultures: Sociocultural Dynamics and the use of resources - theories, methods, perspectives, RessourcenKulturen, 5. Universität Tübingen, Tübingen, pp 11-27

Kolb MJ, Speakman RJ (2005) Elymian regional interaction in Iron Age Western Sicily: a preliminary neutron activation study of incised/ impressed tablewares. J Archaeol Sci 32:795-804

Mathew AJ, Woods AJ, Oliver C (1991) Spots before your eyes: new comparison charts for visual percentage estimation in archaeological material. In: Middleton AP, Freestone IC (eds) Recent developments in ceramic petrology, British Museum Occasional Paper 81. The British Museum, London, pp 211-263

Mohr M (2019) Forschungen auf dem Monte Iato 2018. Antike Kunst 62: $121-134$

Mohr M (2021) Forschungen auf dem Monte Iato 2019 und 2020. Antike Kunst 64:121-126

Mommsen H, Kreuser A, Weber J (1988) A method for grouping pottery by chemical composition. Archaeometry 30-1:47-57

Montana G (2020) Ceramic raw materials: how to recognize them and locate the supply basins-mineralogy, petrography. Archaeol Anthropol Sci 12(8). https://doi.org/10.1007/s12520-020-01130-1

Montana G, Polito AM, Iliopoulos I (2009) Indigenous tableware production during the Archaic period in Western Sicily: new results from petrographic analysis. In: Quinn PS (ed) Interpreting Silent Artefacts. Petrographic Approaches to Archaeological Ceramics. Archaeopress, Oxford (UK), pp 47-63

Montana G, Corretti A, Polito AM, Spatafora F (2011a) Ceramic production in the indigenous settlement of Entella (western Sicily) during Archaic age. In: Memmi I (ed) Proceedings of the $37^{\text {th }}$ International Symposium on Archaeometry, $13^{\text {th }}-16^{\text {th }}$ May 2008 Siena (Italy), Springer -Verlag (Berlin-Heidemberg), Part, vol 1, pp 113-118

Montana G, Cau MA, Polito AM, Azzaro E (2011b) Characterisation of clayey raw materials for ceramic manufacture in ancient Sicily. Appl Clay Sci 53:476-488

Montana G, Polito AM, Sulli A, Caruso A (2011c) Le «argille ceramiche» della Sicilia occidentale e centrale, IlionBooks, Enna (ISBN-10: 8890362626), p. 204

Montana G, Polito AM, Heinze CE, Randazzo L (2012) Archaeometric evidence attesting production of indigenous archaic pottery at Monte Polizzo (Western Sicily). Periodico di Mineralogia 81(1):107-130

Montana G, Polito AM, Tsantini E, (2015) Ceramic ethnoarchaeology in Sicily: recent traditional production as a tool for understanding past manufactures. In Militello, P.M., Öniz, H., (Eds), Proceedings of the 15th Symposium on Mediterranean Archaeology (SOMA, 2011), Catania, 3-5 March 2011. BAR International Series 2695 (I), Oxford (UK), pp 253-258

Montana G, Polito A, Corretti A, Serra A (2017) Compositional reference for the documented Archaic production of indigenous matt-painted pottery at Entella (Western Sicily). Archaeol Anthropol Sci 9(5): 693-708

Montana G, Bechtold B, Polito AM, Randazzo L (2018) Selinunte (Sicily) and its productive context: the clayey raw materials applied in a long-lived ceramic production (seventh to third century BCE). Archaeol Anthropol Sci 10(3):657-673

Montana G, Randazzo L, Blasetti Fantauzzi C (2019) Archaeometric characterization of Late Archaic ceramic from Erice (Sicily) aimed to provenance determination. Int J Conserv Sci 10(4):605-622

Shepard FP (1954) Nomenclature based on sand-silt-clay ratios. J Sediment Petrol 24:151-158

Trombi C (2015) La ceramica indigena decorata della Sicilia occidentale: tipologia e produzione. Casa Editrice Universitas Studiorum, Mantova (Italy), p. 472

Tsantini E, Cau Ontiveros M, Montana G, Randazzo L (2017) The production of traditional building materials in Oristano (Sardinia, Italy). Archaeol Anthropol Sci 9(7):1495-1513

Publisher's note Springer Nature remains neutral with regard to jurisdictional claims in published maps and institutional affiliations. 